\title{
Etableringen af partiet Venstre i Nordslesvig efter genforeningen 1920 Af Agnes Schmidt Poulsen
}

Under fremmedherredømmet med den nationale undertrykkelse havde de dansksindede nordslesvigere stort set med held holdt sammen $p a ̊$ tværs af alle indenrigspolitiske skillelinjer ud fra grundsynet, at de var en befolkning, ikke et politisk parti. Men efter genforeningen opstod der vanskeligheder, da nordslesvigerne skulle finde deres plads i dansk partipolitik. Disse problemer trådte særlig klart frem $i$ forbindelse med etableringen af partiet Venstre $i$ landsdelen. I forvejen kunne landbopartiet Venstre regne med stor sympati, fordi det $i$ nordslesvigernes bevidsthed stod som eksponent for højskolebevægelsen, andelsbevægelsen og i det hele taget den danske, folkelige vækkelse, der havde haft så stor betydning for nordslesvigerne $\mathrm{i}$ fremmedherredømmets tid, og ved det forste folketingsvalg efter genforeningen, den 21. sept. 1920, fik Venstre da også $47 \%$ af de afgivne stemmer i landsdelen, et resultat, der la betydeligt over landsgennemsnittet. Forud for valget havde der imidlertid været stærk diskussion om, hvorledes de mange nordslesvigere med venstresympatier skulle forholde sig organisatorisk over for partiet. De dansksindedes mest fremtrredende fører fra den tyske tid $H$. P. Hanssen og mange med ham gik ind for, at man forelobig i samarbejde med Venstre skulle etablere en selvstæendig sønderjysk venstregruppe, der $p a ̊$ rigsdagen sxerlig skulle tage sig af arbejdet med at lose landsdelens mange sxerproblemer, der fulgte efter genforeningen. I det følgende redegøres mere detaljeret end det hidtil har været muligt for baggrunden for denne tanke, debatten og det politiske spil omkring den og endelig for, hvorledes planen om en selvstændig organisering af et senderjysk Venstre måtte opgives især på grund af modstand fra det kongerigske Venstre, således at de senderjyske venstrefolk alligevel betingelsesløst måtte forsøge at tilpasse sig dansk partipolitik.

POLITISK UDVIKLING FØR APRIL 1920

I årene efter Slesvigs indlemmelse i Preussen 1866 herskede der blandt Nordslesvigs dansksindede befolkning bred enighed om at føre protestpolitik overfor de tyske magthavere. Man påberåbte sig til sta- 
dighed Pragfredens $\$ 5$, hvori en afstemning om nationalt tilhørsforhold stilledes nordslesvigerne i udsigt. Da det i 1879 bekendtgjordes, at paragraffen var ophævet, opstod der i Nordslesvig stridigheder om, hvilken politisk taktik der fremover skulle lægges over for de tyske myndigheder, om bl. a. landdagsmændene skulle aflægge ed på den preussiske forfatning. Denne såkaldte edsstrid mellem edsaflæggere og edsnægtere varede indtil slutningen af 1880-erne og endte med edsaflæggernes sejr. Men om de dansksindedes politik var der stadig modsætninger, som delvis fulgte de gamle linjer. Disse modsætninger uddybedes op mod århundredskiftet, således at der opstod to retninger, protesttilhæengere og forhandlingstilhæengere, som stod skarpt over for hinanden i den i 1888 oprettede fælles politiske organisation, Vælgerforeningen for Nordslesvig (Vælgerforeningen). Forhandlingstilhængernes ledende mand blev redaktør H. P. Hanssen, Hejmdal, som var landdagsmand 1890-1908 og rigsdagsmand 1906-1918. Desuden kan nævnes gårdejer H. D. KloppenborgSkrumsager og gårdejer Nis Chr. Nissen, begge landdagsmænd 19081918. Protesttilhængerne havde en markant leder $\mathrm{i}$ redaktør Jens Jessen, Flensborg Avis, som var rigsdagsmand 1901-1906. Efter Jessens død i 1906 førtes hans politik videre af Ernst Christiansen, Flensborg Avis, A. Svensson, Dybbøl-Posten, og gårdejer Peter Grau, Pøl.

De to fløjes tilknytning til de kongerigske partier kan karakteriseres således, at forhandlingstilhængerne fik støtte fra Venstre, mens Højre sympatiserede med protesttilhængerne.

Ved verdenskrigens udbrud i 1914 stod de to floje omtrent lige stærkt i Vælgerforeningens tilsynsråd, dog med et flertal til forhandlingstilhængerne.

Umiddelbart efter at den tyske regering $i$ begyndelsen af oktober 1918 havde anmodet de allierede om forhandlinger om en våbenstilstand, begyndte H. P. Hanssen åbent at arbejde for Nordslesvigs genforening med Danmark. Hans bestrxbelser gik ud på at få draget en grænse i overensstemmelse med folkenes selvbestemmelsesret, hvilket han krævede $i$ den tyske rigsdag d. 23. oktober. H. P. Hanssen ønskede kun afstået til Danmark, hvad der virkelig var dansk af sprog og sindelag, og hertil regnede han ikke Flensborg. Begge landdagsmænd var enige heri, idet dog H. D. Kloppenborg-Skrumsager senere ændrede holdning med hensyn til Flensborg. 
$\mathrm{Da}$ det ansås for sandsynligt, at en præliminærfred hurtigt ville følge efter våbenstilstandens undertegnelse d. 11. nov. 1918, blev Vælgerforeningens bestyrelse og tilsynsråd med stedfortrædere sammenkaldt til møde d. 16. og 17. november i Ảbenrå for at træffe den endelige beslutning om de krav, der skulle rejses. H. P. Hanssens forslag om samlet afstemning $\mathrm{i}$ området nord om Flensborg og syd om Tønder kunne imidlertid ikke samle enighed, idet nogle talte for afstemning i hele Slesvig, mens andre specielt koncentrerede sig om Mellemslesvig og Flensborg. Den endelige resolution blev et kompromis mellem de forskellige opfattelser. H. P. Hanssens forslag blev vedtaget med en tilføjelse, som gav Mellemslesvig og dermed også Flensborg mulighed for at deltage $i$ en særskilt afstemning.

I forlængelse af de synspunkter, der var kommet frem på Ảbenråmødet, indledtes der derefter en ihærdig agitation for en sydligere grænse end den, H. P. Hanssen og hans meningsfæller var talsmænd for. Under de heftige debatter $i$ vinteren og foråret 1919 om grænsespørgsmålet (bl. a. debatten om en tredje afstemningszone i maj) fremtrådte der to fløje inden for tilsynsrådet, henholdsvis omkring H. P. Hanssen og Nis Nissen (A benråretningen) og omkring P. Grau, H. D. Kloppenborg-Skrumsager og redaktørerne Andr. Grau, Dybbøl-Posten og Ernst Christiansen, Flensborg Avis (Flensborgretningen). Denne deling i grænsespørgsmålet fulgte stort set delingen fra før krigen. ${ }^{1}$

I forbindelse med forventningen om en kommende flytning af den danske grænse mod syd rejste der sig også spekulationer, som drejede sig om forhold efter genforeningen, bl. a. under hvilken form de sønderjyske vælgere skulle repræsenteres på den danske rigsdag. Herom udtalte H. P. Hanssen sig allerede i november 1918. Af et interview $i$ et kongerigsk blad fremgår det, at $H$. P. Hanssen ikke regnede med straks at ville slutte sig til et bestemt parti, men ville blive stående udenfor og som hidtil samarbejde med dem alle. Der ville $\mathrm{i}$ årene efter genforeningen blive så mange sønderjyske spørgsmål at løse, at der ikke ville vare tid til at blande sig i kongerigets. Derfor gik $H$. P. Hanssen ud fra, at de sønderjyske rigsdagsmænd foreløbig ville danne deres eget lille parti. ${ }^{2}$ Indenrigsminister Ove Rode omtaler d. 2. dec. $1918 \mathrm{i}$ sin dagbog en samtale mellem ministeriet og H. P. Hanssen. Under en drøftelse af sønderjydernes kommende deltagelse 
i valg skulle $H$. P. Hanssen havde udtalt, at sønderjyderne ved det første valg ville danne wen særlig gruppe med fraktionstvang i nordslesvigske anliggender, med fuld frihed for medlemmerne i de danske spørgsmål. Senere kunne de så slutte sig til partierne, når de havde set på forholdene med egne øjne. ${ }^{3}$ Det var altså væsentligt for H. P. Hanssen, at de sønderjyske repræsentanter stod sammen i ordningen af deres egne sager. Der var egentlig ikke noget nyt heri, for også i Berlin havde de sønderjyske repræsentanter stået uden for partierne.

Om denne idé om en særlig sønderjysk gruppe stod for H. P. Hanssens egen regning, eller om han har drøftet det med andre forinden, er usikkert; men den synes at have fået en velvillig modtagelse både nord og syd for Kongeåen, hvilket fremgår af nogle udtalelser i 1920. Efter H. P. Hanssens udsagn var en særlig sønderjysk valggruppe oprindelig blevet mødt med forståelse $\mathrm{i}$ kongeriget og havde vundet almindelig tilslutning i Sønderjylland. ${ }^{4}$ Både gårdejer P. J. Refshauge, Oksbøl, dyrlæge C. O. Pedersen, Rødding, og H. D. Kloppenborg-Skrumsager erklærede, at de havde anset en sådan gruppe for berettiget i $1918 .^{5}$ I en forklaring herpå må det være væsentligt at inddrage den uklarhed om grænsespørgsmålet, der herskede $\mathrm{i}$ tiden efter Tysklands kapitulation. Hvis genforeningen kom hurtigt, hvilket var en udbredt opfattelse, ville sønderjyderne ikke kunne nå at organisere sig partipolitisk. Dertil kom, at bevægelsen for en sydligere grænse endnu ikke havde manifesteret sig så stærkt, som det skete efter årsskiftet. Grænsestriden havde således endnu ikke sat så skarpe skel.

I juni 1919 blev H. P. Hanssen medlem af den radikale regering Zahle som minister for sønderjyske anliggender, hvilket gav anledning til en yderligere skærpelse af modsætningerne fra de foregående måneder i Sønderjylland. Som årsager hertil kan nævnes, at H. P. Hanssen dermed trådte ind $i$ en udprxget partiregering, en regering, som var udgået fra Det radikale Venstre, der ikke var særlig populært i Sønderjylland bl. a. på grund af dets tilknytning til brandesianismen og dets holdning $\mathrm{i}$ forsvarsspørgsmålet. ${ }^{6}$ Over for Zahle havde H. P. Hanssen i et brev i maj, offentliggjort i Hejmdal 25. juni 1919, gjort det klart, at eftersom det var hans mening, at de sønderjyske rigsdagsrepresentanter $i$ den første valgperiode burde 
holde sig uden for partierne, måtte det også være en forudsxtning for hans indtræden $\mathrm{i}$ ministeriet, at det ikke på nogen måde måtte kunne udlægges som en partipolitisk tilslutning til ét partis politik. Selv om H. P. Hanssen således benægtede, at hans indtræeden var ensbetydende med partipolitisk stillingtagen, blev han stærkt angrebet af den modsatte fløj. For modstanderne måtte det samtidig være et væsentligt moment, at ministeriet fulgte $H$. P. Hanssens grænsepolitiske linje.

Også i kongeriget skærpedes modsætningerne ved H. P. Hanssens udnævnelse. Det radikale Venstre havde haft regeringsmagten siden 1913 - fra valget i 1918 med Socialdemokratiet som stotteparti. Efter slutningen af krigen kom en stadig voksende uvilje mod ministeriet til udtryk, både i befolkningen og i oppositionspartierne, især på grund af den økonomiske og sociale politik. Dette førte til stærke spæendinger mellem partierne, og Venstre krævede stadig mere højlydt valg.

Dertil kom løsningen af grænsespørgsmålet. På et lukket rigsdagsmøde i oktober 1918 var det lykkedes regeringen at samle partierne omkring en fællesudtalelse, hvori det fastsloges, at nationalitetsprincippet: folkenes selvbestemmelsesret var det foretrukne grundlag for grænsedragningen. Dermed havde partierne tilsluttet sig regeringens politik, Det konservative Folkeparti om end kun nolende, og den danske og sønderjyske politik var samordnet.

Nationalt interesserede kredse kunne dog ikke acceptere regeringens grænsepolitik, og de begyndte, med deltagelse af senderjyske meningsfaller, en kampagne imod $H$. P. Hanssen og regeringen. I denne opposition fremtrådte to retninger. Den ene havde især opmærksomheden rettet mod Mellemslesvig og $\mathrm{i}$ hvert fald Flensborgs genforening (Flensborgbevægelsen), mens den anden arbejdede for et Danmark til Danevirke (Danevirkebevægelsen).

Fra årsskiftet intensiveredes agitationen, og de videregående nationale krav fik $\mathrm{i}$ lobet af foråret 1919 stigende tilslutning ude $\mathrm{i}$ befolkningen. Under indtryk heraf begyndte de konservative at svinge bort fra 1918-erklæringen. Partiet Venstre havde gennem mange år haft forbindelse med H. P. Hanssen, og i oktober 1918 stod J. C. Christensen og hele rigsdagsgruppen, med en enkelt undtagelse, på nationalitetsprincippets grund. Men også dette parti var påvirkeligt 
over for de nationale stemninger, og i løbet af 1919 begyndte både J. C. Christensen og Niels Neergaard at nærme sig Flensborgstandpunktet. Flensborgagitationen havde vel gjort indtryk; men dertil kom, at partiet var $\mathrm{i}$ skred og stod delt på spørgsmålet. Da det for J. C. Christensen var meget væsentligt $i$ disse år at undgå splittelse inden for Venstre, kan hans ændrede holdning samtidig være udtryk for forsøg på at holde partiet sammen. Alligevel fraveg partiet ikke reelt ministeriets politik, idet det stemte sammen med dette ved væsentlige grænsepolitiske vedtagelser (12. maj 1919 og 12. marts 1920). Derimod var der ingen vaklen hos de radikale og socialdemokraterne. De stod fast og fortsatte deres grænsepolitiske linje, hvilket medforte hårde angreb fra modstanderne for at være unationale og tyskvenlige.

Da så H. P. Hanssen uventet og uden forudgående drøftelse med oppositionen blev minister, vakte det voldsom forbitrelse hos Det konservative Folkeparti og Venstre. H. P. Hanssen blev således involveret $\mathrm{i}$ den kongerigske partistrid. De to oppositionspartier anerkendte $\mathrm{H}$. P. Hanssens sagkundskab i sønderjyske spørgsmål, men stod $\mathrm{i}$ modsætning til regeringen og kunne ikke billige den politiske styrkelse, som regeringen derved opnåede. Særlig Venstre irriteredes over, at regeringen udnyttede $H$. P. Hanssens position, hvilket vel også bidrog til, at partiet fjernede sig fra regeringens grænsepolitik. Også imod H. P. Hanssens person rejste der sig vrede inden for Venstre, hvor de fleste havde anset ham for fremtidig venstremand. Set ud fra Venstres synspunkt kunne H. P. Hanssens tanker om, at de sønderjyske repræsentanter $\mathrm{i}$ den danske rigsdag ville stille sig uden for partierne, desuden svække partiets muligheder for at vælte den radikale regering. Efter afstemningen i Sønderjylland, som man regnede med ville finde sted i lobet af kort tid, skulle der afholdes nyvalg til rigsdagen. Med $H$. P. Hanssen som minister $i$ den radikale regering måtte man gå ud fra, at $\mathrm{H}$. P. Hanssen og de sønderjyske repræsentanter ville støtte denne regering og dermed bidrage til at sikre dens vedbliven ved regeringsmagten. ${ }^{7} \mathrm{~J}$. C. Christensen og H. P. Hanssen kom faktisk ikke på talefod med hinanden efter dette.

Syd for grænsen fortsatte grænsestriden med stadig større bitterhed på begge sider, og $\mathrm{i}$ august 1919 sprængtes Vælgerforeningens tilsynsråd $\mathrm{i}$ to grupper: Flensborggruppen og Den nordslesvigske Gruppe 
(af modstandere kaldet Åbenrågruppen). Af hensyn til agitationen før afstemningerne samledes Vælgerforeningen igen i november 1919, dog først efter at der havde været afholdt nyvalg. Valget styrkede Flensborgfløjen; men H. P. Hanssen bevarede et spinkelt flertal.

Ved afstemningen i marts 1920 havde den omstridte by Flensborg tysk flertal. Håbet om byens indlemmelse blev dog ikke dermed opgivet, idet afstemningen kun var vejledende. Grænsen skulle fastsættes af fredskonferencen. Under ledelse af en kreds af Danevirkefolk i Kobenhavn rejste der sig i hele landet en voldsom national belge til fordel for Flensborg. "Flensborg hjem " lød slagordet, altså krav om indlemmelse på trods af stemmetallene. Kredse i Sønderjylland fattede en anden plan. På et møde i Gram d. 16. marts, hvor der foruden representanter for Flensborggruppen også deltog nogle repræsentanter fra Den nordslesvigske Gruppe, fremsattes en plan om internationalisering af 2 . zone og fornyet afstemning efter et vist åremål. Denne plan kunne tænkes at få større tilslutning end kravet om Flensborgs indlemmelse. En sønderjysk delegation bestående af bl. a. H. P. Hanssens meningsfælle Mads Gram, Kobenhoved, henvendte sig til $\mathrm{H}$. P. Hanssen for at få hans støtte til internationaliseringsplanen; men han sagde nej. ${ }^{8}$ Det samme gjorde regeringen med den begrundelse, at internationaliseringstanken lå uden for fredstraktatens rammer. Tilhængerne af internationalisering erkendte da, at hvis der skulle gøres noget for Flensborg inden grænsens endelige fastsættelse, måtte forudsætningen være regeringens fjernelse, hvad især den indflydelsesrige Danevirkekreds i længere tid energisk havde forberedt. Også oppositionspartierne onskede at få ministeriet styrtet; men for J. C. Christensen og Venstre bundede det nxppe $\mathrm{i}$ ønsket om en mere aktiv grænsepolitik. J. C. Christensen og Neergaard havde efter afstemningen i marts erklæret, at man ikke på grundlag af afstemningsresultatet kunne forlange indlemmelse af 2 . zone eller Flensborg. Internationaliseringstanken var de positive overfor, men var klare over, at den stred mod fredstraktaten. 9

Over for de nationale kredses ønske om Venstres medvirken til aktionen mod regeringen var J. C. Christensen tilbageholdende, og først d. 27. marts lod han sig af omdiskuterede grunde overtale af to repræsentanter for den sønderjyske Flensborggruppe, deriblandt H. D. Kloppenborg-Skrumsager, til at udsende et opråb med krav om valg. Grænsespørgsmålet indgik således som et led $\mathrm{i}$ kampen mod 
den siddende regering. Disse bestræbelser førte til den såkaldte påskekrise, hvor kongen d. 29. marts 1920 afskedigede regeringen og indsatte et forretningsministerium, som dog måtte gå efter få dages forløb. Ved et forlig mellem partierne dannedes et nyt forretningsministerium $d$. 5. april, som derefter udskrev valg til d. 26. april.

\section{APRIL 1920}

H. P. Hanssen blev som sønderjysk minister afskediget samtidig med ministeriet Zahle. Dette gav anledning til, at Den nordslesvigske Gruppe $^{1}$ på et møde d. 6. april i Åbenrå vedtog en resolution, hvori der fordredes en genoprettelse af det sonderjyske ministerium. ${ }^{2} \mathrm{På}$ dette tidspunkt var der tilsyneladende endnu ikke afgjort noget herom. H. P. Hanssen forhandlede dagen efter med forretningsministeriet i København. I dette synes der at have varet onske om $\mathrm{H}$. P. Hanssens genindtræeden som sønderjysk minister; men det strandede på modstand fra Venstre og Det konservative Folkeparti. Dertil var H. P. Hanssen blevet en for omstridt person; desuden ville det kunne opfattes som accept af $\mathrm{H}$. P. Hanssens grænsepolitik, og samtidig ville det derved blive tilkendegivet, at det tidligere ministeriums grænsepolitiske linje skulle fortsættes. Også i Nordslesvig modarbejdedes $\mathrm{H}$. P. Hanssens indtræden. Vælgerforeningens Flensborggruppe bad indtrængende $i$ et telegram d. 7. april forretningsministeriet om ikke at udnæevne en minister, som ville modarbejde internationaliseringsplanen. Samme dag meddelte H. P. Hanssen, at han, således som forholdene lå, ikke ville kunne overtage nogen officiel stilling m.h.t. styrelsen af de sønderjyske anliggender, men stillede sig til rådighed, hvis man ønskede at spørge ham til råds. ${ }^{3}$

Flensborggruppens telegram fulgtes op af en resolution på et møde d. 10. april, hvori der udtaltes, at Flensborggruppen nedlagde sen bestemt indsigelse imod, at han [H. P. Hanssen] under nogen som helst form får enebestemmende indflydelse på ledelsen af de sønderjyske anliggender og kræver, at såfremt $\mathrm{H}$. P. Hanssen benyttes som rådgiver af regeringen, en repræsentant for Flensborggruppen, da stilles ved hans side. I den ovrige del af resolutionen udtales en ubetinget mistillid til H. P. Hanssens politik. ${ }^{4}$ D. 22. april droftede Den nordslesvigske Gruppe situationen, og $\mathrm{i}$ den vedtagne resolution tilkendegav gruppen sin fulde tillid til tidligere minister H. P. Hanssens 
politik og ønsket om, at han igen måttet blive i stand til at fortsætte det store arbejde til gavn for den sønderjyske befolkning og hele Danmark. ${ }^{\mathbf{5}}$

Mens Valgerforeningens Flensborggruppe $i$ en resolution takkede de borgerlige partier for deres indsats, ${ }^{6}$ faldt der på Den nordslesvigske Gruppes møde 6. april flere kritiske bemærkninger om Venstres deltagelse $i$ regeringen Zahles afskedigelse. Samtidig kom en stærk interesse for Venstre til udtryk bl. a. om dets stilling til internationationaliseringsplanen. ${ }^{7}$ Under valgkampen forholdt Hejmdal sig kritisk over for Venstre, hvad en del kongerigske venstreblade blev stødt over. $^{8}$

Af væsentlig betydning for de følgende måneders begivenheder var det, at H. P. Hanssen på det ovennæunte møde d. 22. april direkte over for sine meningsfæller fremsatte sin gamle tanke om, at de sønderjyske rigsdagsrepresentanter skulle stille sig uden for partierne. Planen synes ellers ikke at have varet sxrlig meget fremme i den offentlige debat, sikkert fordi genforeningen trak ud, og der var andre spørgsmål, der var mere dominerende. Først fra begyndelsen af 1920 dukkede den for alvor op igen, idet H. P. Hanssen nævnte den $i$ et interview, hvorefter pressen begyndte at beskxftige sig med spørgsmålet. D. 27. marts fremkom Dannevirke-Modersmålet i Haderslev med en artikel, hvori tanken om en særlig sønderjysk gruppe blev varmt anbefalet. Der pegedes på, at der i nogle år ville være mange særlige sønderjyske spørgsmål, der skulle tages stilling til. Ved afgørelsen af disse ville de sønderjyske rigsdagsmænds stemmer få større vægt, når de optrådte samlet, end hvis de gik ind i partierne. Bladet, som kun få dage tidligere var blevet et venstreblad, opfattede ikke tilslutningen til en sønderjysk gruppe som værende i modstrid til partidelingen på rigsdagen. Kun i sønderjyske anliggender burde de sønderjyske rigsdagsmænd stemme sammen, ellers var de frit stillet. Til slut hed det $\mathrm{i}$ artiklen, at der var betydelige dele af det danske folk, som ventede, at Sønderjyllands genforening skulle kunne virke »som en fornyelse, en renaissance, ikke mindst partipolitisk.* Dette ville ikke ske, hvis sønderjyderne blot prøvede på wat udråbe nogle gængse kongerigske partifraser med endnu sterre kraft end vore landsmænd nord for Kongeåen. Fornyelsen skulle snarere bestå $i$, at det særlig partipolitiske blev trængt noget i bag- 


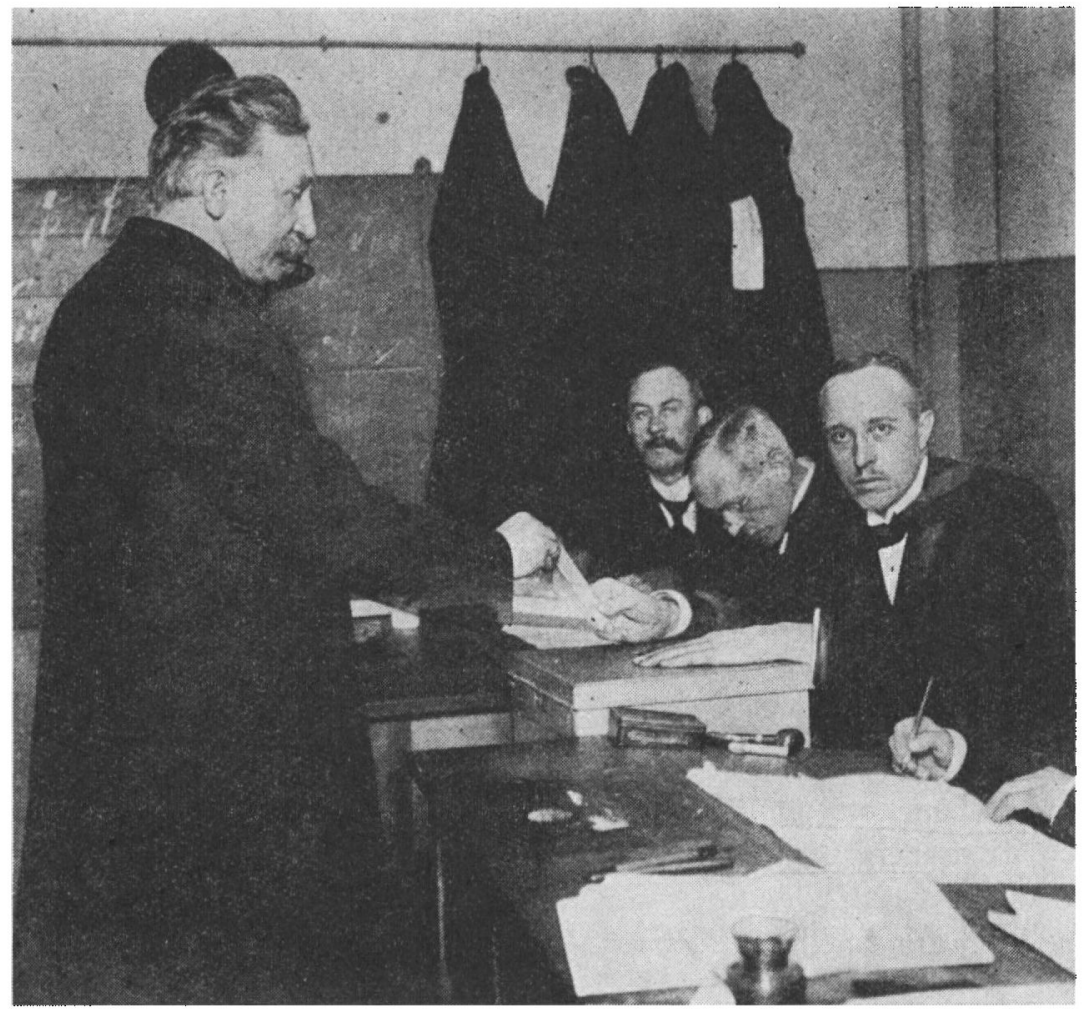

H. P. Hanssen, der som rigsdagsmand 1906-18 bavde varet den nordslesvigske danskbeds samlingspunkt, afgiver sin stemme $i$ Abenrd ved folkeafstemningen den 10. feb. 1920. - Ved sin indtreden som sonderjysk minister $i$ det radikale ministerium Zable var Hanssens forbold til partiet Venstre blevet sterkt belastet, og det bidrog pa forband til at vanskeliggøre realiseringen af hans plan om etableringen af en sonderiysk sarrepresentation pd Rigsdagen i tilknytning til Venstre. (Historiske Samlinger for Sonderjylland)

grunden, og det fælles danske kom noget mere til sin ret. ${ }^{9}$ Kongerigsk partipolitik havde man åbenbart ikke meget tilovers for.

D. 22. april fremhevede H. P. Hanssen, at tiden var kommet til at tænke på det kommende valg, og pointerede stærkt, at de sønderjyske rigsdagsmænd burde stå sammen og føre sønderjysk politik, altså tanken om en sønderjysk valggruppe. Det fremgår af hans oplæg, at han ikke var i tvivl om, at gruppen kunne få en stærk stilling på rigsdagen. "Nu rykker vi ind $\mathrm{i}$ en tid, hvor der er balance 
mellem partierne ... Så er det os, der bliver tungen på vægtskålen.* Det var ikke en løs gruppering af de sønderjyske rigsdagsmænd, H. P. Hanssen forestillede sig. Han foreslog, at der skulle nedsæettes et udvalg til at udforme et program for det kommende valg. Der blev ikke vedtaget noget herom, og det blev ikke nævnt i resolutionen. ${ }^{10}$

Derimod enedes man om at udbygge organisationen af Den nordslesvigske Gruppe. I de forskellige indlæg blev det fremhævet, hvor vigtigt det var med en organisation; flensborgerne var dem overlegne. Den nordslesvigske Gruppe havde hidtil kun omfattet $H$. P. Hanssens meningsfaller i Vxlgerforeningen; men nu skulle der nedsættes udvalg $i$ alle amter, således at gruppen fik tillidsmænd $i$ hver kommune. Man aftalte at mødes senere til en større grundlovgivende forsamling. "11 Af udtalelsen om flensborgerne og andre lignende kunne man udlede, at Den nordslesvigske Gruppes organisering var tænkt som et modtræk mod Flensborggruppen.

At $\mathrm{H}$. P. Hanssen pludselig agiterede så energisk for en sønderjysk valggruppe på rigsdagen og en udvidelse af Den nordslesvigske Gruppe må vel skyldes, at forretningsministeriet ikke havde genindsat ham som minister, således at han var afskåret fra indflydelse på de sønderjyske anliggender, hvad han på mødet udtalte stor fortrydelse over. ${ }^{12}$ Desuden synes han også at være blevet opfordret af nogle meningsfaller. Gårdejer M. Refslund Poulsen, Bovlund, oplyser, at han og J. H. Schmidt, Vojensgård, søgte at få H. P. Hanssen til at danne en gruppe. ${ }^{13}$

\section{MAJ - JUNI 1920}

\section{Regeringsdannelsen efter valget d. 26. april 1920}

Ved valget d. 26. april 1920 vandt Venstre en stor valgsejr og blev opfordret til at danne regering. Allerede før valget havde J. C. Christensen skrevet til Neergaard, at når han, J. C. Christensen, efter al sandsynlighed efter valget blev kaldt til kongen, ville han pege på Neergaard som regeringsdanner. Selv ville J. C. Christensen ikke danne regering og angav som årsag, dels ulyst, dels at han var så stærkt angrebet udefra. ${ }^{1}$ Sandsynligvis belært af erfaringen fra tidligere år ønskede Neergaard ikke at danne en regering, hvor J. C. Christensen stod udenfor. Først da J. C. Christensen indvilligede $\mathrm{i}$ at træde ind i ministeriet, bøjede han sig. ${ }^{2}$

Ved forhandlingerne $\mathrm{i}$ forbindelse med regeringsdannelsen gav 
Venstres forhold til $\mathrm{H}$. P. Hanssen anledning til nogle bevægede og langvarige drøftelser. Efter aftale ankom højskoleforstander Jacob Appel, Askov, til Neergaard d. 3. maj om aftenen. Over for denne erklærede Appel åbent, at han havde lyst til at blive minister igen, men havde betænkeligheder, idet han frygtede et brud med H. P. Hanssen. Derfor ønskede han først at have en samtale med denne. Neergaard gjorde det klart, at han hverken ville gøre H. P. Hanssen til minister eller generalkommissær, men tænkte sig en tremandskommission, bestående af tre medlemmer fra Vxlgerforeningen, en fra hver af grænsestridens to grupper og en fra Sønderjysk Arbejderforening. ${ }^{3}$ Dermed blev H. P. Hanssen orienteret om Venstres stilling.

H. P. Hanssen rådede indtrængende Appel til at indtræde $\mathrm{i}$ regeringen, hvorefter Appel den følgende dag meddelte Neergaard, at han gerne ville modtage en ministerpost. Ifølge Neergaard lagde Appel megen vægt på, at Neergaard fik talt med H. P. Hanssen. ${ }^{4}$ At Appel ikke har stået alene med et sådant ønske om kontakt mellem Venstre og H. P. Hanssen kan et brev fra Anders Lebeck, Dannevirke, til $H$. P. Hanssen tyde på. Gennem Lebeck sendte kongerigske venstrefolk hilsner til $H$. P. Hanssen. Når valget 26 . april var overstået, skulle han få at føle, at hans venner i Venstre ikke havde glemt ham. ${ }^{5}$

Senere på dagen d. 4. maj kom en aftale i stand gennem Appel. Neergaard har omtalt denne samtale, som efter hans indtryk "forlob under venlige former, men dog røbede ikke ringe bitterhed fra hans [H. P. Hanssens] side. Indledningsvis havde Neergaard meddelt H. P. Hanssen, »at ministeriet ønskede så lidt som muligt at indblande sig i de sønderjyske partiforhold og ville stille sig venligt til begge sider.\& Derefter havde han omtalt planen om tremandskommissionen, som H. P. Hanssen afviste. Han anså et samarbejde med en mand fra Flensborggruppen $i$ en sådan kommission for udelukket; efter hans opfattelse ville heller ikke hans meningsfaller indlade sig på noget sådant. ${ }^{6} \mathrm{H}$. P. Hanssen havde tidligere taget afstand fra kommissionstanken over for Den nordslesvigske Gruppe med den begrundelse, at en kommissær ingen indflydelse havde, idet han var afskåret fra at deltage $i$ minister-og rigsdagsmøder. ${ }^{7}$

Venstre havde således ikke $\mathrm{i}$ sinde at give $\mathrm{H}$. P. Hanssen enerådende myndighed $i$ sønderjyske sager, heller ikke $i$ en venstrerege- 
ring. Det ville ganske givet også have mødt megen modstand blandt partiets Flensborgfolk og have stødt sønderjyske Flensborgvælgere bort. $^{8}$ Dertil kom forholdet til Det konservative Folkeparti, som støttede regeringen. Dette parti var absolut ikke velvilligt stemt over for H. P. Hanssen. I stedet fremkom Neergaard med et kompromisforslag, hvorved Den nordslesvigske Gruppe ikke blev udelukket, men sidestillet med Flensborggruppen. Samtidig forsikrede han H. P. Hanssen, at partiet ville stille sig venligt til begge sider; det ville ikke blande sig og ikke tage parti.

\section{Venstreregeringens grensepolitik}

Regeringens grænsepolitiske linje blev fastlagt d. 4. maj, hvor det på et møde mellem ministrene vedtoges at støtte en mellemslesvigsk delegation, som få dage senere afrejste til Paris for at søge tilslutning til planen om internationalisering af 2. zone. Vedtagelsen skete først efter en længere forhandling, under hvilken Appel ifølge Neergaard *udtalte betænkelighed ved at indlade sig for dybt med Flensborgmændene. «9 På ministermødet d. 6. maj foreslog Neergaard at sende en særlig delegeret til Paris for at støtte delegationen. Men regeringen ville dog ikke gøre delegationens forslag til sit og ville ikke selv fremsætte noget forslag, så længe de sejrende magter ikke havde tilkendegivet, at internationalisering lå inden for fredstraktatens rammer. ${ }^{10}$ Regeringen støttede således på den ene side internationaliseringstanken, men bandt sig på den anden side ikke til at fore en aktiv grænsepolitik, idet den ikke gav løfte om noget regeringsinitiativ. I det hele taget synes regeringen ikke at have regnet med internationalisering som en sandsynlig mulighed. ${ }^{11}$

D. 26. maj fastsattes grænsen på fredskonferencen uden, at internationaliseringsplanen kom $i$ betragtning, og $d$. 15. juni stadfæstede de allierede magter Nordslesvigs overdragelse til Danmark. Den danske konge underskrev traktaten d. 9. juli, og i de følgende dage fandt genforeningsfestlighederne sted i Sønderjylland.

\section{Dannevirke-Modersmålet}

Det skarpe modsæetningsforhold, der opstod mellem de to sønderjyske grupper $\mathrm{i}$ striden om grænsens fastsættelse, gav sig konkret udslag bl. a. $i$ en strid ved bladet Dannevirke, der ejedes af aktieselskabet Modersmålet. Striden varede indtil 1923 og drejede sig om, hvilke 
af de to fløjes synspunkter, der skulle dominere bladet. I grænsespørgsmålet stod både redaktion, tilsynsråd og aktionærkreds delt. Den ene af de to ansvarshavende redaktører A. Lebeck gik fuldt og helt ind for H. P. Hanssens politik og fremsatte med skarphed sine standpunkter i grænsespørgsmålet, hvilket førte til hårde angreb mod ham fra modpartens side. Da chefredaktør Nic. Svendsen forlod bladet i februar 1920, modsatte Flensborgorienterede aktionærer sig, at Lebeck afløste denne. På en generalforsamling d. 23. marts vedtoges det, at Dannevirke skulle være et venstreblad. Som chefredaktør ansattes d. 1 . juli en kongerigsk venstremand M. Strandskov Nøhr. I perioden indtil da dominerede Lebeck bladets holdning, dog i stadig modsætning til Flensborgfolkene, som på en generalforsamling d. 10. maj sikrede sig flertal i direktion og tilsynsråd. Modsætningen inden for bladet fortsatte også efter ansæettelsen af den nye redaktør. Bl. a. blev nogle af Lebecks artikler om en særlig sønderjysk gruppe stoppet $\mathrm{i}$ juli måned. ${ }^{12}$

\section{Den nordslesvigske Gruppes forhandling om en sarlig sønderjysk gruppe}

I begyndelsen af maj kunne Dannevirke meddele, at en kreds af Den nordslesvigske Gruppes meningsfæller havde holdt en sammenkomst i Haderslev østeramt, og at det samme ville ske i vesteramtet. Hensigten var at supplere Den nordslesvigske Gruppe, så den blev et mere fyldigt udtryk for de anskuelser, der fandt udtryk i H. P. Hanssens nationale politik. ${ }^{13}$

D. 12. maj blev Den nordslesvigske Gruppe og meningsfæller fra alle egne af Nordslesvig, ialt ca. 350 deltagere, indbudt til møde $i$ Ảbenrå. Forskellige emner drøftedes; men hovedformålet med mødet var de delegeredes stilling til dansk partipolitik. H. P. Hanssens standpunkt var velkendt inden mødet, og ifølge Refshauges erindringer havde de delegerede fra Haderslev østeramt drøftet deres stillingtagen inden d. 12. maj. Refshauge havde da bestemt rådet fra at gå med til en sønderjysk gruppe, og man enedes om at gå imod oprettelsen. Da Refshauge ikke selv kunne deltage d. 12. maj, har det så været de øvrige tillidsmænd, der skulle fremføre østeramtets synspunkter. ${ }^{14}$

Mødet indledtes af $\mathrm{H}$. P. Hanssen, der gav en længere redegørelse for den politiske situation. Det bemærkes, at der blandt deltagerne 
viste sig stor interesse for at få en orientering om Venstres standpunkt i grænsespørgsmålet.

I forlængelse af drøftelserne d. 22. april valgtes et repræsentationsudvalg på 14 medlemmer fra hele Nordslesvig, hvis opgave bestod $i$, som det hed i Hejmdals referat, at "gøre gruppens politiske opfattelser gxldende overalt i Nordslesvig.«

Under droftelsen af holdningen ved det kommende valg fremsatte H. P. Hanssen sin gamle idé om, at de sønderjyske rigsdagsmænd ved det første valg og $\mathrm{i}$ den første valgperiode burde holde sig uden for de politiske partier $i$ kongeriget. Selv ville han $i$ hvert fald ikke ind $i$ noget parti. Som tidligere henviste $H$. P. Hanssen til de mange særlige sønderjyske spørgsmål, som han mente bedst løstes af sønderjyderne selv, når de stod samlet uden at være bundet af de forskellige partier. En samlet gruppe kunne bedre sætte sine krav igennem. Hovedopgaven $i$ overgangstiden var varetagelsen af de nordslesvigske interesser, »der selvfølgelig of te vil komme til at stå $i$ modsætning til de kongerigske. $H$. P. Hanssen synes her ikke at nære megen tiltro til, at rigsdagens partier ville lytte til de sønderjyske rigsdagsmænds ønsker. Han forestillede sig ligefrem et modsætningsforhold. Hans ministertid og regeringen Venstres desavouering af ham kun få dage tidligere har vel nxppe kunnet undgå at påvirke ham. Selv om han i sit oplæg havde skelnet skarpt mellem nordslesvigsk og dansk, tilføjede han dog samtidig, at det ikke var hensigten at føre sønderjysk særpolitik. Gruppen skulle opløses efter den første valgperiode. Derved ville de sønderjyske vælgere også få tid til at orientere sig partipolitisk, inden de delte sig efter danske partilinjer. H. P. Hanssen betragtede således gruppen som et nødvendigt overgangsled til dansk partipolitik.

Mens H. P. Hanssen i forelæggelsen omtalte formålet med gruppen, dens funktion og varighed, nævnte han intet om dens vælgergrundlag. Hvad havde han tænkt sig m.h.t. Flensborggruppen? I Hejmdals referat står der kun "vi«, og intet om hvem det dxkker. H. P. Hanssen tog det for givet, at gruppen stod samlet som en enig blok. Flensborggruppen var ikke indbudt til dette møde, ikke engang orienteret på forhånd, d.v.s. at kun den ene af grænsestridens to retninger var repræsenteret, hvilket på forhånd kunne tænkes at indskrænke det grundlag, gruppen skulle baseres på. Var det bevidst fra $H$. P. Hanssens side, eller troede han, at han kunne samle hele 
den sønderjyske befolkning på disse præmisser, således at han ligesom tidligere kunne representere sønderjyderne på trods af indre modsætninger? I 1918 tænkte han sig, at en sonderjysk gruppe skulle repræsentere hele Nordslesvig, men her i 1920 kunne noget tyde på, at $\mathrm{H}$. P. Hanssen simpelthen ikke har onsket at tage hensyn til Flensborggruppen. Det erindres, at han d. 4. maj havde meddelt Neergaard, at han anså et samarbejde med Flensborggruppen i en kommission for udelukket. Desuden kan nævnes valget af et repræsentationsudvalg og udbygningen af organisationen, som netop skulle bidrage til at styrke Den nordslesvigske Gruppe.

De efterfølgende talere på mødet d. 12. maj sluttede sig til H.P. Hanssens synspunkter med undtagelse af Mads Gram, som bl. a. udtalte: »Grænsespørgsmålet har delt befolkningen; men denne deling vil være ophørt, når først afgørelsen i grænsespørgsmålet er truffet, og det ville være en fejl at opretholde den. Så kunne vi blive befriet for de gamle synder, der hxeftede ved den. Vi er mange, der mener, at vi skal opgive den gamle gruppering og se at finde vore pladser i dansk politik efter de herskende politiske rettelinjer.« Mads Gram var en gang tidligere gået imod H. P. Hanssens politik ved i samarbejde med Flensborgfolk at tage initiativ til internationaliseringsplanen i marts, hvilket havde skaffet ham en del kritik fra meningsfxllernes side. Gram har sikkert ikke følt sig så starkt bundet til Den nordslesvigske Gruppe og har vel ikke haft svært ved at se bort fra grænsestridens skel. Anders Lebeck derimod stattede fuldt og helt H. P. Hanssen og hans plan. Han fandt det naturligt, at de fulgte den mand, som indtil da havde stået som deres fører. Også i de øvrige indlæg stottedes tanken om en særlig sønderjysk gruppe, men samtidig udtaltes interesse for samarbejde med Flensborggruppen. F. eks. mente gdr. Chr. E. Christensen, Asserballe, at sønderjyderne var forbundet ved fælles interesser; der måtte kunne opstilles et program, der kunne samle dem alle.

Drøftelsen resulterede i en beslutning om, at bestyrelsen, som bestod af Nis Nissen, kaptajn C. C. Fischer, Ảbenrå, og gårdejer Olav Fink, Brændstrup, skulle suppleres med yderligere to medlemmer, Martin Simonsen, Flovt, og Th. Thomsen, Toghale, således at alle amter blev representeret. Denne udvidede bestyrelse fik til opgave at undersoge, om der inden for Flensborggruppen var stemning for et samarbejde. H. P. Hanssen tilsluttede sig denne tanke. 
Ved mødets slutning udtalte Olav Fink, at der ville "blive gjort et ærligt forsøg på samling «; men det skete på et tidspunkt, hvor Den nordslesvigske Gruppe havde været samlet for at drøfte en sønderjysk gruppe. ${ }^{15}$

Til slut kan man spørge, om udfaldet af dette møde svarede til H. P. Hanssens forventninger. Under forhandlingerne fremhxvede H. P. Hanssen, at det kun var hensigten at fremkalde udtalelser om en sønderjysk gruppe; der skulle ikke tages beslutninger, hvilket heller ikke blev tilfaldet. Ifølge Hejmdal var der bred enighed om det ønskelige $i$ at danne en gruppe, saledes som $H$. P. Hanssen havde foreslået det. Omfanget af modstanden mod planen kom sandsynligvis ikke klart frem på mødet. Refshauge skriver, at ifølge de øvrige tillidsmænd fra østeramtet havde $\mathrm{H}$. P. Hanssen afgjort sagen og afsluttet mødet, uden at de fik mulighed for at komme til orde med deres protest. Efter mødet mente Refshauge ikke, at han kunne gøre noget, da planerne var offentliggjort, og han nødig ville være med til at krenke H. P. Hanssen. ${ }^{16}$ Måske har denne respekt for eller loyalitet mod H. P. Hanssen været grunden til Refshauges fravær d. 12. og til østeramtets tillidsmænds tavshed. Væsentligt for H. P. Hanssen må det imidlertid have været, at Refshauge, der var en betydningsfuld mand $\mathrm{i}$ østeramtet, ikke engang kom til mødet. Desuden kan nævnes, at der blandt mødets deltagere var overvejende stemning for, at Flensborggruppen blev inddraget $i$ forhandlingerne, hvad H. P. Hanssen ikke selv havde taget initiativ til; men han viste sig dog ikke uvillig. Mødet svarede øjensynlig ikke til H. P. Hanssens forventninger, idet han sikkert havde ventet en kraftigere opbakning fra sine meningsfaller.

Både Hejmdal og Dannevirke støttede planen, og i den følgende tid fremkom en del artikler, hvori der argumenteredes for gruppen. Argumentationen indeholdt stort set ingen nye momenter. ${ }^{17} \mathrm{En}$ enkelt undtagelse skal nævnes her. Dannevirke fremhævede $i$ maj, at bl. a. tyskerne havde store chancer for at bjerge stemmer, hvis de kongerigske partiinteresser blev sat $\mathrm{i}$ første række og de sønderjyske $\mathrm{i}$ anden. De danske vælgere burde stå sammen og ikke splitte stemmerne på flere partier. ${ }^{18}$ Det samme gentoges af $\mathrm{H}$. P. Hanssen i juni.19 Man spillede på det gammelkendte tema, som måske nok kunne gøre indtryk. 


\section{Flensborggruppens reaktion}

D. 14. maj drøftede Flensborggruppen i Flensborg sin holdning til dansk partipolitik. Hvordan og hvorfor mødet kom i stand vides ikke. ${ }^{20}$ Formodentlig må det ses som en reaktion på Den nordslesvigske Gruppes møde et par dage i forvejen. Heller ikke indholdet af debatten kendes; derimod en resolution derfra, som blev offentliggjort. Det var enstemmig blevet vedtaget, at gruppen ikke som sådan skulle tage stilling til indre dansk politik. »Gruppen ønsker den gamle Kongeå-grxnse slettet fuldt og helt og fraråder på det bestemteste særslesvigske partidannelser samt anbefaler ved det kommende valg at støtte de partier, der har antaget sig alle danske sønderjyders sag og arbejder på en for vore sydlige forposter muligst betryggende løsning af grænsespørgsmålet. «21 Dermed havde Flensborggruppen klart tilkendegivet, at den tog afstand fra den påtrenkte sønderjyske gruppe. Resolutionen gav de enkelte meningsfaller mulighed for frit at organisere sig efter danske partilinjer, idet gruppen ikke opfordrede til samlet at gå ind $i$ et bestemt parti. Ifølge Flensborg Avis skulle Det konservative Folkeparti i begyndelsen af maj måned have fremsat tilbud om, at Flensborggruppen samlet trådte ind i partiet, hvilket var blevet afvist. ${ }^{22}$ Hvilke partier, der i realiteten kunne være tale om, fremgår af resolutionens afslutning, som på forhånd udelukkede tilslutning til Det radikale Venstre og Socialdemokratiet.

Hvordan Flensborgfolkene har opfattet udspillet fra Den nordslesvigske Gruppe kan fornemmes af Flensborg-venstrebladet Dybbel-Postens kommentarer og af et par indlxg af C. O. Pedersen i maj måned i Dannevirke. Det grundlag, på hvilket Den nordslesvigske Gruppe søgte etableret et samarbejde med Flensborggruppen, afvistes blankt af $C$. O. Pedersen. Kun ved at dele sig efter danske partilinjer havde man mulighed for at komme bort fra »den unaturlige skillelinje«, som grxnsestriden havde sat. Den samme opfattelse havde Dybbøl-Posten. ${ }^{23}$

I det hele taget kunne C. O. Pedersen ikke indse nødvendigheden af en sønderjysk gruppe, der specielt skulle varetage sønderjydernes interesser, for alle partier på rigsdagen havde hidtil enstemmigt været villige til at yde det mest mulige for sønderjyderne, så derfor behøvede de ikke at opføre sig, som om de havde med en modstander at gøre. Desuden ville en sønderjysk gruppe være for lille til at få no- 
gen indflydelse på rigsdagen, og den havde ingen mulighed for at blive tungen på vægtskålen. Dertil havde det siddende venstreministerium et for stort flertal bag sig. Derimod kunne de sønderjyske repræsentanter $f_{a}^{\circ}$ stor indflydelse inden for de enkelte partier og kunne udmærket samtidig arbejde sammen om sønderjyske spørgsmål. ${ }^{24}$ En sønderjysk gruppe som overgangsled til dansk partipolitik anså C. O. Pedersen heller ikke for nødvendig. Vælgerne behøvede ikke nogen overgangstid for at kunne tage stilling; de vidste godt, om de hørte hjemme "på den ene eller den anden side af den store skillelinje i dansk politik. «25 Denne udtalelse må ses på baggrund af den stadigt stigende spænding mellem regeringspartierne og oppositionen indtil marts 1920 og forløbet af påskekrisen. Nogle af de sønderjyske Flensborgfolk havde deltaget aktivt i bestræbelsen på at styrte regeringen $Z$ ahle.

At en sonderjysk gruppe skulle kunne formindske tyskernes valgchancer, afviste C. O. Pedersen. Tværtimod ville de snarere øges, ved at gruppen måtte opstille særlister. Desuden henvistes til den danske valglov, hvorefter mandaternes fordeling skulle ske efter forholdstalvalgmåden, således at et tysk mindretal nxppe kunne udelukkes. ${ }^{26}$

C. O. Pedersen anså ligefrem en sådan gruppe for skadelig og også uigennemførlig. I stedet for at fjerne de gamle skel ved Kongeåen ville en sønderjysk gruppe fremme slesvigsk partikularisme, som tidligere havde været så ødelæggende for landet. Den var uigennemførlig, fordi der mellem Flensborggruppen og Den nordslesvigske Gruppe havde været uenighed ikke alene om grænsespørgsmålet, men også om mange andre spørgsmål. En sønderjysk gruppe ville falde fra hinanden ved første lejlighed på grund af indre meningsforskelle.27

Til slut skal nævnes endnu en begrundelse, som C. O. Pedersen fremførte for Flensborggruppens afstandtagen fra en sønderjysk gruppe. Efter hans opfattelse var hovedgrunden for ønsket om at danne en sådan gruppe, at $\mathrm{H}$. P. Hanssen ikke kunne slutte sig til noget bestemt parti. Fundamentet for partiet var $H$. P. Hanssen og Nis Nissen, og på et sådant fundament var samling med Flensborggruppen udelukket. H. P. Hanssen formåede ikke mere at være samlingsmærke i nordslesvigsk politik, den tid var uigenkaldeligt forbi. ${ }^{28}$

Til trods for, at Flensborggruppen udtalte vilje til at slette grænsestridens modsætninger, ses det dog, at dens holdning til en sønder- 
jysk gruppe i høj grad var bestemt heraf. Flensborggruppen kunne simpelthen ikke stotte en partidannelse, som var udgået fra Den nordslesvigske Gruppe og da slet ikke med H. P. Hanssen som den centrale person. I tilknytning hertil synes også de partipolitiske forhold at spille ind. C. O. Pedersen fastslog, at med Den nordslesvigske Gruppes beslutning var alle muligheder for samling udtømt, og hvert parti måtte gå sine egne veje. ${ }^{29}$

Som nævnt var der inden for Flensborggruppen enighed om, at Sønderjylland skulle organiseres politisk efter de samme linjer som det øvrige Danmark, og allerede d. 14. maj havde C. O. Pedersen i et indlæg i Dybbøl-Posten opfordret sønderjyderne til at organisere sig partipolitisk. For sit eget vedkommende gik han ind for oprettelsen af venstreorganisationer og begyndte kort tid efter at afholde møder for at få sådanne oprettet. Det første fandt sted $\mathrm{i}$ Tønder d. 30. maj, og den følgende dag dannedes den første vælgerforening i Sønderjylland i Tønder amt. Også i Sønderborg påbegyndtes arbejdet. D. 28. maj afholdtes privat et møde $\mathrm{i}$ byen, hvor man enedes om at oprette en venstreforening. Der blev nedsat et udvalg for Sønderborg amt på 11 mand, som skulle indkalde til det officielle stiftelsesmøde. Blandt initiativtagerne $\mathrm{i}$ dette amt kan nævnes Andr. Grau, Dybbøl-Posten. 30

De venstreorganisationer, der søgtes dannet $\mathrm{i}$ hele Sønderjylland, var åbne for alle; men tilslutningen kom fortrinsvis fra flensborgsk side. Dannevirke betragtede dem med megen mistro og hævdede, at de nydannede venstreorganisationer var en ny form for Flensborgagitation. $\mathbf{3 1}$

Disse første forsøg på at få oprettet venstreforeninger skete på sønderjysk initiativ uden aktiv kongerigsk deltagelse, men bl. a. Andr. Grau havde nær kontakt til Venstres ledere og holdt Neergaard underrettet om udviklingen m.h.t. dannelsen af vælgerforeninger. Ud over at holde Venstre orienteret gjorde bl. a. Andr. Grau ihærdige forsøg på at få tilsagn fra partiet om støtte. I et brev d. 30. maj til Neergaard henviste Grau til, at kredse inden for Den nordslesvigske Gruppe ikke havde lyst til at være med til at starte et særligt nordslesvigsk parti. De ville helst slutte sig til Venstre, men nærede betxnkeligheder ved at bryde med H. P. Hanssen. Det ville derfor, efter Graus mening, være af den allerstørste betydning om de sønderjyske venstrefolk kunne regne med støtte fra Venstre under valg- 
kampen, wikke blot i almindelig forstand, hvad der jo ikke kan være tvivl om, men i den forstand, at Venstres førere kommer herned og griber aktivt ind $i$ valgkampen ved at støtte vore kandidater.* Samtidig bad han indtrængende Neergaard om at tale ved et offentligt venstremøde i Sønderborg efter genforeningsfesterne. ${ }^{32}$ Andre kongerigske venstrepolitikere fik lignende henvendelser fra Sønderjylland om at deltage i sønderjyske møder til støtte for arbejdet for Venstres organisation.

De kongerigske partiers, iser Venstres, stillingtagen

Graus brev giver indtryk af, at han tilsyneladende ikke var helt sikker på Venstre, hvordan det ville stille sig til begivenhederne i Sønderjylland, og om det ville deltage aktivt i valgkampen. Det var i og for sig ikke uforståeligt, for Venstre havde endnu ikke taget stilling, kun havde Neergaard meddelt H. P. Hanssen, at partiet ikke ville blande sig. Men på et partimøde d. 3. juni drøftedes de sønderjyske henvendelser, og der var enighed om at vente med at tage arbejdet op til efter genforeningen. ${ }^{33}$ Det er uklart, hvad der mentes med udtrykket mefter genforeningen $\ll$. Venstre påbegyndte ikke agitationen hverken efter 15. juni eller 9. juli; men i slutningen af juli måned udtalte J. C. Christensen, at Venstre først ville begynde, når sønderjyderne var trådt ind i det politiske liv i Danmark, altså først efter grundlovsændringen i september. Venstre havde åbenbart ikke hastværk med at komme ind i Sønderjylland. ${ }^{34}$

Om de ovrige kongerigske partiers stilling kan det nævnes, at Det radikale Venstre forholdt sig afventende, hvorimod Det konservative Folkeparti og Socialdemokratiet indledte deres agitation henholdsvis i juni og juli. Ifølge Hejmdal afholdt de konservatives formand, landstingsmand Piper et møde i Tønder d. 6. juni for at få dannet en organisation, og d. 18. juni samledes konservative tilhæengere $i$ Haderslev. ${ }^{35}$ Også Socialdemokratiet, der som det eneste af partierne havde fodfreste i Sønderjylland før 1920, begyndte at afholde moder. Allerede i foråret 1920 var der blandt de sonderjyske socialdemokratiske partiforeninger stort set opnået enighed om at tilslutte sig det danske socialdemokrati. I juni meddeltes det fra Socialdemokratiet, at de sønderjyske partiforeningers indmeldelse $i$ det danske parti var 


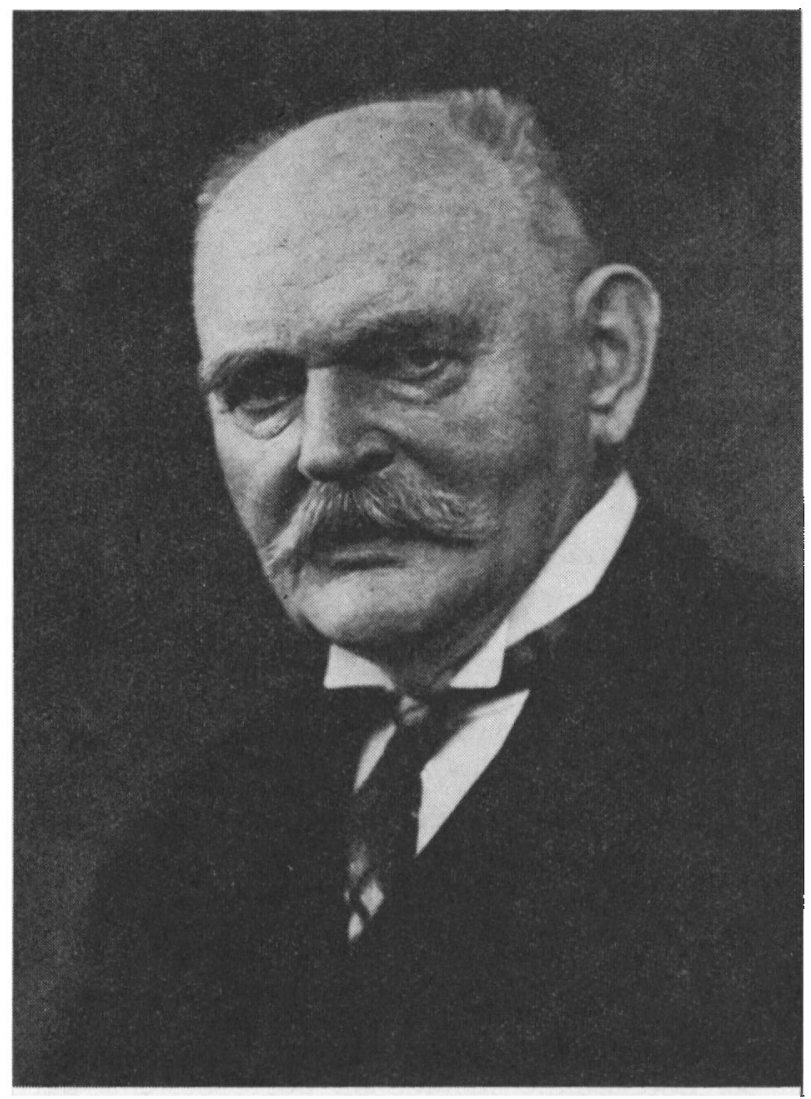

Venstrepolitikeren Niels Neergaard (1854-1936), statsminister 1920-24. (Det kongelige Bibliotek)

fastsat til d. 1. juli. Stauning skulle have talt ved et møde i Haderslev i slutningen af maj, men det aflystes. Det første møde fandt sted i Haderslev d. 17. juli. ${ }^{36}$

Situationen $i$ juni

Hvordan det egentlig gik med planen om en særlig sønderjysk gruppe i tiden efter mødet d. 12. maj, er der ikke fundet konkrete oplysninger om. 
Tilsyneladende var der heller ikke straks gjort alvorlige skridt til dannelsen af en sønderjysk gruppe. I et brev d. 27. juni til Nis Nissen efterlyste Hans Fink handling. Han havde længe gået og tænkt på og vidste også, at andre havde gjort det samme, hvad det egentlig blev til med en sonderjysk gruppe, »skal vi roligt afvente, at landet oversvømmes af partiprofeter nordfra, som opretter organisationer i hveranden by? « Han syntes, det var på høje tid, at Den nordslesvigske Gruppe fik et program, så folk vidste, hvad den ville, og at den $i$ det hele taget ville noget. ${ }^{37}$ Planen var ikke opgivet, hvilket ses af en omtale i Hejmdal d. 16. juli af et udvalg, som var blevet nedsat »for nogle uger siden « for at udarbejde vedtægter for en sønderjysk valggruppe. ${ }^{38}$

Ledelsen havde altså tøvet længe med at handle, hvilket kunne skyldes, at der var uenighed inden for Den nordslesvigske Gruppe, således at der kunne herske tvivl om tilslutning til planen. Hejmdal gav det $\mathrm{i}$ månederne efter mødet $\mathrm{d}$. 12. maj $\mathrm{i}$ artikler tydeligere og tydeligere udseende af, at gruppen var en kendsgerning, ja endda at der klart og utvetydigt var taget beslutning. ${ }^{39}$ Måske var man ved Hejmdal $\mathrm{i}$ tvivl om tilslutningen og ville på den måde påvirke meningsfællerne. Tvivlende var åbenbart Hans Fink, for han skrev d. 27. juni, at hvadenten de blev mange eller få, så skulle de danne en senderjysk gruppe, men måske under et andet navn. Det vigtigste var at få valgt $H$. P. Hanssen og Nis Nissen, hvilket han troede let kunne lade sig gøre, hvis man tog fat inden alt for længe. Han vidste, at mange ikke kunne stemme på noget bestemt parti ved det første valg, men mærkede også, at mange var ved at lade sig indfange af partierne. ${ }^{40}$

Imidlertid var det endnu ikke konstateret, hvordan stillingen var, for Den nordslesvigske Gruppe havde ikke taget stilling til en konkret plan om en sønderjysk gruppe, som indbefattede et program. Situationen kan således på dette tidspunkt betegnes som uafklaret. Ligeledes udadtil. Ganske vist kunne man ikke regne med Flensborggruppen, og af de kongerigske partier ville de konservative og socialdemokraterne ikke respektere en sønderjysk gruppe. Derimod var forholdet mellem Venstre og Den nordslesvigske Gruppe ikke afklaret. $\mathrm{Da} \mathrm{H}$. P. Hanssen i maj fremsatte sit forslag om en særlig sønderjysk gruppe, skete det uden forudgående aftaler med de kongerigske partier, men allerede inden da havde Neergaard over for ham 
tilkendegivet, at Venstre ikke ville blande sig i de indre sønderjyske partiforhold.

\section{JULI 1920}

\section{Samtaler d. 10. juli}

Da Flensborggruppens venstrefolk var kommet godt i gang med organiseringen, blev Lebeck øjensynlig bekymret for en sønderjysk gruppes muligheder. Han skrev d. 5. juli til $H$. P. Hanssen og spurgte ham, om han ville være villig til at tale $i$ Haderslev sammen med statsminister Neergaard, hvis Lebeck kunne få det ordnet. Han mente, det ville virke gavnligt over for »den dyrlæge Pedersen'ske agitation «. "Venstres velvillige holdning over for dig og Den nordslesvigske Gruppe er jo forudsætningen for dette. $\alpha^{1}$ Lebeck var således ikke fremmed over for tanken om en vis forståelse mellem Venstre og Den nordslesvigske Gruppe. Ja, han antydede ligefrem, at hvis Venstre tog afstand fra en sønderjysk gruppe, kunne den ikke opretholdes. Samtidig ville en velvillig holdning fra Venstre indebære et alvorligt knæk for Flensborggruppens Venstre.

H. P. Hanssens svar kendes ikke, men d. 10. juli under genforeningsfestlighederne i Haderslev henvendte Lebeck sig til Neergaard om sagen. ${ }^{2}$ Ifølge Neergaard havde Lebeck fremhxvet, at det omtalte møde kunne tjene til at bane vejen for den sammenslutning med Venstre, som langt de fleste inden for Den nordslesvigske Gruppe onskede. Neergaard måtte dog først vide, om gruppen ville slutte sig til Venstre. Hertil skulle Lebeck have svaret: "Ikke straks - vi ville ikke kunne gore det allerede nu uden at ofre vore ledende mænd [H. P. Hanssen og Nis Nissen], men det må og skal blive enden på det! « Dette kunne Neergaard ikke acceptere; hvad det drejede sig om, var stillingen ved det forestående valg. Der ville blive opstillet venstrekandidater vistnok $i$ alle sønderjyske kredse, og ved at tale ved et møde, som var baseret på en sønderjysk særpolitik med opretholdelsen af en særlig gruppe $i$ den kommende valgperiode, ville han komme til direkte at modarbejde de sonderjyder, som med det samme ville slutte sig til Venstre. Lebeck anmodede så Neergaard om at tale med H. P. Hanssen samme aften, hvilket afvistes; Neergaard anså det ikke for opportunt. ${ }^{3}$ Derimod opsøgte han under opholdet i Sønderjylland Andr. Grau på hans kontor, men traf ham ikke. ${ }^{4}$ Sådan som Neergaard har refereret samtalen, kunne der ikke være tvivl 
om Venstres holdning. Man kunne ikke støtte H. P. Hanssen, og Neergaard ville end ikke tale med denne. I Lebecks optegnelser findes et kort notat om samtalen, som viser, at Lebeck ikke var tilfreds med udfaldet. ${ }^{5}$

Senere på dagen talte Lebeck dog med andre ledende venstrepolitikere, undervisningsminister Appel og landbrugsminister Th. Madsen-Mygdal, og fandt her større velvilje. Lebeck skriver, at han gav stødet til, at de to venstrepolitikere om aftenen besøgte $H$. P. Hanssen; $^{6}$ men det skete dog ikke uden efter aftale med Neergaard. Dermed kunne de, som Neergaard udtrykte det, fra forste hånd fà at vide, hvordan stillingen var. Neergaard konkluderede ud fra Appels referat af samtalen med $H$. P. Hanssen, at den havde fået et utilfredsstillende forløb. Appel og Madsen-Mygdal havde gjort det klart for $H$. P. Hanssen, at når om få uger venstrekandidater og kandidater for en sønderjysk gruppe stod over for hinanden, ville de første få støtte af venstrepolitikere fra kongeriget. Dette ville uundgåeligt øge modsætningerne og kaste gruppen $\mathrm{i}$ armene $\mathrm{på} \mathrm{de} \mathrm{radi-}$ kale. Heroverfor havde $\mathrm{H}$. P. Hanssen udtalt, at i modsxtning til Venstre havde de radikale ført en konsekvent grænsepolitik. I de sønderjyske sager var der meget, der ikke gik, som det skulle, så der ville blive god brug for en sønderjysk gruppe, hvis centrale opgave ville blive kritikken. $\gg H$. P. Hanssens holdning var helt igennem kølig og alt andet end imødekommende«, skriver Neergaard. Til slut havde Appel og Madsen-Mygdal udtrykt ønske om, at nogle repræsentanter fra Venstre fik lejlighed til at tale med tillidsmændene for Den nordslesvigske Gruppe, inden det nye parti blev dannet. Hertil skulle $H$. P. Hanssen have svaret undvigende; tillidsmændene måtte dog først selv have et møde. ${ }^{7}$

Helt så negative som Neergaards optegnelser giver indtryk af, synes forhandlingerne ikke at have været. Der var dermed skabt en kontakt mellem $\mathrm{H}$. P. Hanssen og venstrerepræsentanter, og konkrete samarbejdsformer havde tilsyneladende været på tale, hvilket skulle vise sig at blive af afgørende betydning for den følgende tids begivenheder. H. P. Hanssen oplyste $i$ august, at Appel og MadsenMygdal fortroligt havde givet tilbud om en alliance mellem Venstre og en sønderjysk gruppe ved valget. ${ }^{8}$ Neergaard har ikke omtalt et sådant forslag; måske var han uvidende om det. Forholdet mellem Neergaard og H. P. Hanssen kunne vel ikke ligefrem betegnes som 
hjerteligt i denne periode, hvilket bl. a. fremgår af Neergaards optegnelser: Til mig personlig gjorde H. P. Hanssen under hele rejsen ingen tilnærmelser, skønt jeg hilste særlig på ham ved kongemodtagelsen i Ảbenrå«. Dette tilskyndede ikke til en tilnærmelse. Neergaard synes personlig stødt. Set på baggrund af Appels forhold til H. P. Hanssen forekommer det derimod ikke utænkeligt, at Appel har gjort, hvad han kunne for at få bragt en ordning $i$ stand mellem H. P. Hanssen og Venstre. Over for Neergaard havde han desuden udtalt stor betænkelighed ved den nordslesvigske særpolitik, som ville blive en følge af $\mathrm{H}$. P. Hanssens planer. En sønderjysk gruppe skulle bekæmpes, og Venstre måtte gribe ind. ${ }^{9}$

Sådan som Neergaard har gengivet forlobet af forhandlingerne, kunne det se ud, som om Venstre ved en afvisende holdning over for $H$. P. Hanssen har villet presse ham til at opgive sine planer; men han stod stejlt fast. Han nærmest provokerede ved at fremhæve Det radikale Venstres fortjenester. Måske har de to politikere dernæst tænkt, at Venstre bedre kunne påvirke meningsfællerne. En sådan konfrontation var H. P. Hansssen åbenbart ikke interesseret i. Velsagtens frygtede han en splittelse inden for Den nordslesvigske Gruppe, hvis nogle ikke kunne modstå Venstres tilnærmelser. Mads Gram havde jo d. 12. maj anbefalet tilslutning til de kongerigske partier. Som en sidste udvej har så Appel og Madsen-Mygdal formodentlig foreslået en alliance.

H. P. Hanssen omtalte ikke Appels og Madsen-Mygdals tilsagn over for sine meningsfæller, fordi de efter hans egne oplysninger var af fortrolig art, og der spores ingen holdningsændring hos ham i den følgende tid.10 Forslaget havde åbenbart ikke hans interesse.

\section{Den sønderjyske Gruppe}

D. 16. juli meddelte Hejmdal, at det udvalg, der var nedsat til at udforme et udkast til program for en sønderjysk valggruppe, var blevet færdig, således at udkastet kunne udsendes til de ca. 400 tillidsmænd i dagene omkring d. 16. juli.

Programudkastet bestod af 10 paragraffer, hvoraf den første angav, at partiets navn var Den sønderjyske Gruppe. Derefter fulgte partiets hovedopgave, som gik ud på wat gennemføre de sønderjyske landsdeles sammensmeltning med det ovrigt rige på en sund, rolig 
og frisindet måde og $\mathrm{i}$ en muligst kort overgangstid. « Af de enkelte programpunkter kan nævnes: statsstotte til krigens ofre, til genrejsning af erhvervslivet, til udbygning og forbedring af trafikvæsenet og til byernes vakst. Nationalpolitisk skulle der ydes vidtgående kulturel støtte til det danske mindretal syd for grænsen, ligesom det tyske mindretal skulle garanteres fuld kulturfrihed. Som retningslinje for det almindelige lovgivningsarbejde angives til slut, at partiet ville støtte en frisindet og fremskridtsvenlig politik. Det ville gå ind for sociale reformer, for social udsoning og for en ordning af forholdet mellem arbejder og arbejdsgiver.

Sammen med programudkastet fulgte en indbydelse til møde $d$. 23. juli i Åbenrå »for at drøfte og vedtage programmet og tale om opstilling af kandidater til de forestående valg til folketing og landsting. ${ }^{11}$ Tillidsmændene blev indtrængende bedt om at komme, da der skulle tages vigtige beslutninger, og sagen hastede. Indbydelsen var underskrever af Nis Nissen. Partiernes organisationsarbejde og Venstres holdning havde åbenbart ikke afskrækket H. P. Hanssen, men måske bidraget til, at sagen hastede. I Hejmdal blev det d. 17. juli oplyst, at Den nordslesvigske Gruppes organisation ville blive fuldendt i løbet af nogle uger.

\section{Flensborgvenstres reaktion på samtalerne d. 10 . juli}

Imidlertid blev mødet mellem H. P. Hanssen og de to venstrepolitikere kendt, og rygterne begyndte hurtigt at svirre. ${ }^{12}$ På baggrund heraf henvendte Andr. Grau sig d. 18. juli atter til Neergaard. Rygtet sagde, at $H$. P. Hanssen efter valget ville søge ind $i$ Venstre, og at han allerede gennem landbrugsministeren og undervisningsministeren skulle have fået "tilsagn om en vis støtte - om end kun passiv - under den forestående valgkamp for sig og sin nordslesvigske gruppe. « Grau påpegede over for Neergaard, at sådanne rygter havde indflydelse på udviklingen i Sønderjylland i øjeblikket. D. 23. juli ville der blive oprettet en venstreforening i Sønderborg, som sluttede sig »i ét og alt til Venstre." Det ville ikke blive en ny form for Flensborggruppen; der var fra starten adskillige mænd fra Den nordslesvigske Gruppe med. M.h.t. Venstres udsigter i Sønderjylland var det imidlertid afgørende, om de senderjyske venstreforeninger kunne regne med støtte fra Venstres ledende mænd imod Den nordslesvig- 
ske Gruppe under valgkampen. Hvis det blev tilfældet, ville Venstre have gode muligheder på Als og Sundeved. Stillede Venstre sig derimod ikke klart eller måske passivt, ville Sundeved blive en sikker konservativ valgkreds, og Als ville gå til Den nordslesvigske Gruppe. Grau antog, at stillingen var noget lignende over hele Nordslesvig.

Grau ønskede at få rede på Venstres stilling til Den nordslesvigske Gruppe ved de forestånde valg, ja, han mente endog, at de havde krav på at få klar besked, jo før jo bedre. Han hørte ikke til dem, der ikke kunne stå i parti sammen med $\mathrm{H}$. P. Hanssen og forlangte ingen garantier for, at denne aldrig optoges i Venstre. Foreløbig måtte $\mathrm{H}$. P. Hanssen efter Graus mening "sejle sin egen sø med sin nordslesvigske gruppe. "Hvis Venstre fik stor tilslutning, ville H. P. Hanssen, som den store opportunist han var, dog engang melde sig ind i partiet; i hvert tilf $x$ lde ville flertallet af hans valgere. En radikalisering af vælgerne kunne H. P. Hanssen ikke gennemføre. ${ }^{13}$

Grau var her tydeligt nervøs over Venstres stilling og søgte at presse Neergaard, dels ved at fremhæve Venstres muligheder i Sønderjylland, dels ved at berolige med at flertallet af Den nordslesvigske Gruppe trods alt senere ville melde sig ind i Venstre, ikke i Det radikale Venstre. Ligesom Appel drog også Grau H. P. Hanssens forhold til de radikale frem. Set på baggrund af spændingen mellem partierne på rigsdagen har dette sandsynligvis været et væsentligt moment. Neergaards svar d. 10. juni på Graus brev af 30 . maj om støtte havde åbenbart ikke beroliget Grau. Dette kunne tyde på, at Neergaard ikke havde givet så klart udtryk for Venstres standpunkt over for Grau, som han havde ladet det ske over for H. P. Hanssen.

\section{Andreas Thulstrups aktivitet}

D. 20. juli skrev H. P. Hanssens tidligere medarbejder $i$ det sønderjyske ministerium, cand. jur. Andr. Thulstrup, fra Kobenhavn til H. P. Hanssen. Han havde været i Haderslev og havde der haft lejlighed til at tale med flere meningsfæller om valgforberedelserne og programspørgsmålet. Disse havde til hans store forbavselse udtalt, "at befolkningen i Haderslev østeramt ville stemme »Venstre«, d.v.s. forlangte, at kandidaterne ved det forestående valg tog stilling til de danske partiforhold og sluttede sig til Venstre. « Thulstrup ville derfor foreslå at kalde gruppen "Sønderjysk Venstre«, selv om der der- 
ved var fare for, at en del meningsfæller faldt fra. ${ }^{14}$ Thulstrup gjorde det således klart for H. P. Hanssen, at Den sønderjyske Gruppe ikke kunne realiseres uden splittelse af Den nordslesvigske Gruppe; et kompromis var nødvendigt, *Venstre* måtte indgå i navnet. Om Thulstrup selv havde fundet på det, eller om han var budbringer for meningsfallerne i Haderslev østeramt kan ikke ses; men det er vel ikke utænkeligt, at man har drøftet, hvilke muligheder, der var for samling. Ifølge forslaget skulle en særlig sønderjysk gruppe opretholdes, blot under et andet navn. Hvorvidt forslaget indeholdt mere, kan der kun gisnes om. Sådan som Thulstrup har gengivet de haderslevske meningsfællers udtalelser, kunne det tyde på, at de ønskede en nærmere tilknytning til Venstre.

Allerede d. 21. og 22. juli, altså lige efter afsendelsen af brevet til H. P. Hanssen, førte Thulstrup samtaler med Appel..$^{15} \mathrm{Hvem}$, der havde taget initiativet til disse, fremgår ikke af materialet. Muligvis har Thulstrup opsøgt Appel efter at have hørt om østeramtets modstand. Hvad samtalerne drejede sig om kendes fra et telegram og brev fra Thulstrup til Appel d. 24. juli. De drøftede en ordning mellem Venstre og Den nordslesvigske Gruppe. Ordningen, som de ifølge Thulstrup enedes om, gik ud på, at partiet skulle kalde sig Det sønderjyske Venstre og slutte alliance med rigsdagens Venstre m.h.t. spørgsmålet om tillægsmandaternes fordeling. Venstre skulle så ikke opstille venstrelister i de sønderjyske landsdele.

Disse samtaler førte Appel åbenbart for egen regning, for da bladet København omkring d. 21. juli henvendte sig til J. C. Christensen for at få at vide, hvordan Venstre vurderede sønderjydernes politiske stilling efter genforeningen, tog han skarpt afstand fra ideen om en sønderjysk gruppe. Ligeledes var han meget afvisende over for H. P. Hanssen. Da han blev spurgt om, hvad han troede, H. P. Hanssen havde til hensigt med en sådan gruppepolitik, svarede han, at det vidste han ikke. "Jeg søger ham ikke. Når han søger mig, taler jeg med ham; men han har ikke sogt mig i dette tilfælde. Jeg synes heller ikke, der er nogen grund for mig til at rende ham på dørene, efter at han lod sig optage i det radikale ministerium. ${ }^{\mathbf{1 6}}$

Venstres leder blev dog ikke enstemmig bakket op af partiets presse. F. eks. havde Ringsted Folketidende givet udtryk for, at man skulle »unde de hjemvendte tid til at prøve den politiske valuta, der bydes. $\ll 17$ 


\section{Den nordslesvigske Gruppes møde d. 23. juli}

Inden Den nordslesvigske Gruppes møde d. 23. juli i Ảbenrå henvendte Refshauges meningsfaller i Haderslev østeramt sig til ham, for at han nu skulle tage med. Denne gang slap han altså ikke. På mødedagen tog et stort antal deltagere fra Haderslev østeramt samlet af sted til Ảbenrå, og på vejen dertil blev alle deltagere enige om, at dannelsen af en sønderjysk gruppe så vidt muligt burde forhindres. Refshauge blev bedt om at fremsxtte østeramtets synspunkt på mødet.

Inden mødets begyndelse skal H. P. Hanssen have spurgt Refshauge om Haderslev østeramts stilling til Den sønderjyske Gruppe. Refshauge anså planen for umulig, men nu da den var offentliggjort, var det ikke let at komme bort fra den. I stedet foreslog han, at der oprettedes et parti, Sønderjysk Venstre, med tilslutning til Venstre, og at en deputation blev sendt til København for at få klarhed over, hvordan Venstre stillede sig. Efter Refshauges udsagn havde H. P. Hanssen erkendt gruppens vanskelige stilling og været velvillig stemt over for Refshauges tanker; men han kviede sig ved at gå ind i Venstre efter det, der var gået forud. ${ }^{18} \mathrm{Da}$ Refshauge ikke har beskrevet sit forslag nærmere, er det ikke muligt at se, hvad det nøjagtigt gik ud på. En ting fremgår dog klart: gruppen skulle bibeholdes; men samtidig skulle den tilsluttes Venstre. Væsentligst er det vel nok, at man ønskede kontakt med Venstre. Også Thulstrup havde et møde med H. P. Hanssen, hvorunder han redegjorde for sine samtaler $\mathrm{i}$ København med Appel. 19

Den nordslesvigske Gruppes tillidsmænd var indkaldt til møde for at drøfte og vedtage programmet for Den sønderjyske Gruppe. Dette blev skudt i baggrunden, idet formanden Nis Nissen foreslog, at man tog en generaldebat, om dannelsen af en selvstrendig gruppe skulle fastholdes. ${ }^{20}$ Baggrunden herfor var holdningen i Haderslev osteramt. Efter at H. P. Hanssen havde meddelt, at han stadig stod på sit gamle standpunkt, indledte Refshauge debatten. Stemningen i Haderslev østeramt var delt; men den var måske overvejende for ikke at danne en særlig gruppe. ${ }^{21}$ Af indlxgget ses, at især to forhold var afgørende for Refshauges modstand, dels af grænsepolitisk, dels af partipolitisk art. $\mathrm{Da}$ den sønderjyske befolkning ikke kunne samles, ville der kun kunne dannes en gruppe, der bestod af $\mathrm{H}$. P. Hanssens meningsfaller i grænsespørgsmålet. Kløften mellem de to grup- 
per ville uddybes, fordi Den nordslesvigske Gruppe formodedes at have sympati for de partier, som Flensborggruppen ikke kunne have med at gøre. Også for Haderslev østeramt spillede det partipolitiske spørgsmål en rolle. $\gg \mathrm{Og}$ vi vil være sikrede overfor, at det ikke er en tilsløret radikalisme, vi går med til. ${ }^{22}$ Nis Nissen protesterede imod udtrykket »tilsløret radikalisme«; han ville ikke ind i noget parti. Flere østeramtsfolk sluttede sig i de efterfølgende indlæg til Refshauge. "Befolkningen forlanger et klart standpunkt.\& I andre indlæg, hvor repræsentanterne for de øvrige amter redegjorde for deres indtryk af stemningen på deres egn, støttedes H. P. Hanssens plan. Eksempelvis mente M. Refslund Poulsen ikke, at folk var klar over deres standpunkt. Venstreforeningerne dannedes næsten udelukkende af Flensborgfolk og havde kun tilslutning blandt disse. På hans egn var man absolut stemt for en sønderjysk gruppe, også blandt de mange af Sønderjysk Arbejderforenings medlemmer. En delegeret fremhævede national samling $i$ enighed mod tyskerne, og en anden sagde, at det store flertal på hans egn ikke havde nogen indsigt i dansk politik. »Refshauge protesterede imod Refsl. Poulsens overlegne tone. Vi er klare over, hvilke partier vi ikke tilhører. $\star^{23}$

$\mathrm{Da}$ diskussionen efter Thulstrups udsagn begyndte at blive »hidsig og samtidig ørkesløs, " brød Thulstrup ind og sagde, at Appel havde foreslået navnet "Sønderjysk Venstre og alliance med Venstre ved fordeling af tillægsmandaterne. ${ }^{24}$ Derefter fortsatte forhandlingerne. Fra Haderslev østeramts repræsentanter blev det forlangt, at man skulle holde sig til højre for skillelinjen i dansk politik, og endnu engang blev H. P. Hanssen og Nis Nissen opfordret "til at tone rent flag «; men Nissen kunne ikke slutte sig til Venstre, »efter den storsnudede udtalelse af J. C. Christensen. « Repræsentanter fra Sønderjysk Arbejderforening ønskede ikke at komme ind i dansk "partikævl«; derimod trængtes til en udjæuning af de sociale modsætninger, hvilket en særlig sønderjysk gruppe kunne bidrage til. Ligesom tidligere af bl. a. Refslund Poulsen blev det fremhæevet, at menigmand ikke var moden til at tage standpunkt. Som en af de delegerede udtrykte det, så kendte man den danske nordslesvigske politik og havde hidtil fulgt $\mathrm{H}$. P. Hanssen. Det ville være mærkeligt at svigte ham nu. I flere lignende udtalelser blev der lagt vægt på, at det var H. P. Hanssen og Nis Nissen, man ønskede valgt.

Indtil da havde $\mathrm{H}$. P. Hanssen holdt sig uden for debatten, men 
tog nu ordet. Han stod fast på, at han under ingen omstændigheder ville træde ind $i$ et bestemt parti $i$ overgangstiden. Hovedopgaven var løsningen af de sønderjyske spørgsmål; han havde ikke lyst til at arbejde med de windre danske småting. « Det var den sønderjyske politik, der skulle samle gruppen. Gruppens størrelse kom det ikke så meget an på, for den skulle ikke virke som lod på vægtskålen, men ved sin sagkundskab med regeringen og partierne. I sin argumentation for en sønderjysk gruppe lagde $H$. P. Hanssen her stor vægt på forholdet til det tyske mindretal. Først nævnte han, at en sønderjysk gruppe kunne drage hjemmetyskerne til sig i stedet for, at de sluttede sig til den tyske valgerforening. Dette synes dog kun muligt, hvis gruppen specielt ville føre en slesvigsk politik, hvad H. P. Hanssen netop havde taget afstand fra. Senere sagde han derimod, at tyskheden kunne være så stærk, at en splittelse af danskerne kunne blive farlig. I Danmark undervurderede man tyskheden.

I sin omtale af Venstre synes H. P. Hanssen ligesom Nis Nissen bitter og skuffet over partiets holdning. »Det, der vanskeliggør en indtræden $\mathrm{i}$ Venstre, er den grænsepolitik, som Venstre har ført. Vi er ikke bleven støttet af Venstre, skønt $V$. ikke $i$ realiteten har fastholdt de beslutninger, de har taget, og det er den stadige modsætning mellem Venstre og mig. « Men også det, at han ikke blev genindsat som minister, ser ud til at have påvirket hans vurdering af Venstre.

Han kom med nogle kritiske bemærkninger om dets ledelse af den sønderjyske politik. Venstres almindelige politik havde han derimod fra sin ungdom haft sympati for.

Refshauge svarede, at ingen nærede mere bitterhed mod Venstre end han; men nu gjaldt det ikke grænsesporgsmålet, derimod dansk politik. Han ønskede H. P. Hanssen og Nis Nissen valgt ind, men forlangte, at de gik ind $i$ et parti. Thulstrups forslag var han positiv overfor. Han opfattede Appels udtalelse til Thulstrup som en bro og udtalte, at Thulstrup måske kunne fremsxtte de retningslinjer, der tilfredsstillede dem. Andre delte denne opfattelse; man var bange for, at en sønderjysk gruppe skulle hælde til radikal-socialistisk side.

Derefter fulgte en længere drøftelse af partiets navn. En del udtalte tvivl om navnet "Venstres samlende muligheder, da det kunne virke afskrækkende på vælgere med en anden politisk overbevisning. Især fremhævedes dette af Sønderjysk Arbejderforenings repræsentanter. Andre, deriblandt Chr. E. Christensen, Asserballe, pegede på, 


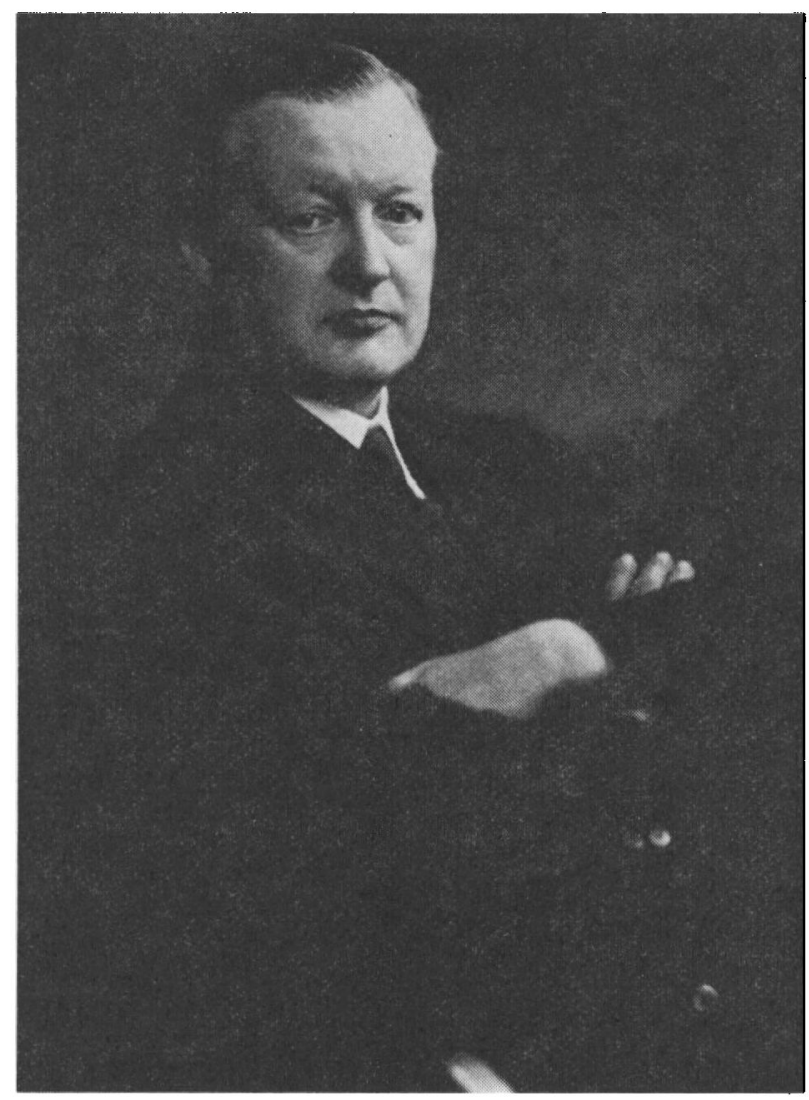

Andreas Grau (1883-1935), fra 1919 redaktor af Dybbol-Posten, der stottede Flensborgretningen. I 1920 var Grau en af de ledende Flensborg-venstrefolk, der begyndte at oprette deres egne venstreforeninger og derved bidrog til at umuliggore $H . P$. Hanssens planer om samling $i$ et serligt sonderjysk venstre. (Dansk Centralbibliotek for Sydslesvig)

at *Venstre « ikke var et bånd for deres repræsentanter. Venstre blev betragtet som et frisindet parti. Nis Nissen havde ikke noget imod "Venstre«, men ville ikke sendes til København med bundne hænder. H. P. Hanssen udtalte sig ikke.

Resultatet af droftelserne blev, at en del af de deltagere, der havde støttet tanken om en sønderjysk gruppe, bøjede sig for Haderslev østeramt. Som Refslund Poulsen udtrykte det, hvis østeramtet øn- 
skede at få *Venstre« med, så ville han gå med. ${ }^{26}$ Andre kunne ikke overbevises om "Venstres samlende muligheder, hvilket afstemningen om partiets navn viste, idet Det sønderjyske Venstre vedtoges med 110 stemmer mod $84 .{ }^{27}$

Derefter nedsattes et udvalg på 12 delegerede til at udforme et program, som vedtoges enstemmigt. Dette program fik omtrent samme indhold som Den sønderjyske Gruppes, blot $i$ en noget kortere form (6 paragraffer). ${ }^{28}$ En enkelt ændring skal dog nævnes. Thulstrup kunne berolige Appel med, at ordet "stat « ikke længere omtaltes så stærkt i programmet. ${ }^{29}$ I Den sønderjyske Gruppes program forekom ord som statsunderstøttelse, statshjelp, statskredit o.s.v., hvilket nok har virket for »radikal-socialistisk « for en venstremand.

Efter ønske fra de delegerede fra Haderslev østeramt nedsattes til slut et femmandsudvalg, som fik til opgave i København at forhandle med Venstre om tillægsmandater og få Venstre til at afholde sig fra at opstille kandidater i Sønderjylland. Udvalget kom bl. a. til at bestå af H. P. Hanssen, Nis Nissen og M. Refslund Poulsen. ${ }^{30}$ Refshauge var blevet foreslået; hans navn er opført i listen af udvalgsmedlemmer, men er streget over og erstattet af et andet. Selv skriver han, at han havde udspekuleret en god undskyldning, da han nødig ville for dybt ind $\mathrm{i}$ politik. ${ }^{31}$ Måske ønskede han ikke at stå over for Venstres ledere som repræsentant for en sønderjysk gruppe. Ifølge hans udtalelser på mødet havde han jo helst set en indmeldelse $\mathrm{i}$ Venstre, men kunne åbenbart ikke distancere sig fra $\mathrm{H}$. P. Hanssen.

Mødet resulterede altså i dannelsen af en særlig sønderjysk gruppe, Det sønderjyske Venstre, som skulle samarbejde med Venstre. Et program var blevet vedtaget, således som det udtaltes $\mathrm{i}$ indbydelsen; men gruppen havde fået et andet navn (et kongerisk partinavn), og kandidatopstilling var slet ikke kommet på tale. Først skulle der forhandles med Venstre, hvis stillingtagen gruppen måtte være afhængig af. Det var gået anderledes end forudsat $i$ indbydelsen. Hvem var ophavsmand til planen om Det sønderjyske Venstre, og hvordan blev planen modtaget?

H. P. Hanssen synes ikke at have været involveret $\mathrm{i}$ Thulstrups private samtaler med Appel; han forholdt sig tilsyneladende passiv og afventende $i$ denne tid. Men Thulstrup orienterede ham inden $d$. 23. og påstod senere, at han på mødet havde refereret samtalerne 
med Appel efter anmodning af H. P. Hanssen. Thulstrup var derimod aktiv, og som han skrev opsat på at få en wfornuftig ordning " i stand. ${ }^{32}$ Thulstrup kan imidlertid ikke have været ophavsmand til planen. Han deltog bl. a. ikke i sammenkomsten d. 10. juli. Det gjorde til gengæld Appel, som allerede da skulle have givet H. P. Hanssen et lignende tilsagn. På mødet d. 23. juli sagde Thulstrup, at det var Appels forslag. At Appel spillede en central rolle fremgår af, at Thulstrup allerede samme dag sendte ham et telegram for at meddele ham resultatet af mødet. "Der blev i dag efter mit forslag under henvisning til vore samtaler opnået enighed om oprettelse af et sønderjysk Venstre med alliance med Venstre ved fordelingen af tillægsmandaterne under forudsætning af, at Venstre derefter undlader at opstille særlister som omtalt under vore samtaler. «s $^{\text {Is }}$ et efterfølgende brev skrev han, at de beslutninger, som var taget, helt nøje stemte overens med indholdet af deres samtale. Appels forbindelse med planen er her tydelig. Endelig kan det nævnes, at Thulstrup efter mødet var blevet stærkt kritiseret af flere meningsfæller; man havde bl. a. beskyldt ham for at være Appels lejesvend. ${ }^{34}$ Sammenholdes dette med den store interesse, Appel $i$ maj og juli viste for at få en ordning i stand mellem Venstre og $\mathrm{H}$. P. Hanssen, forekommer det sandsynligt, at han har været ophavsmand til planen.

Da der indenfor Den nordslesvigske Gruppe herskede enighed om, hvordan gruppen skulle lade sig repræsentere politisk, kan løsningen med Det sønderjyske Venstre betegnes som et kompromis, der $\mathrm{i}$ hvert tilfælde holdt Den nordslesvigske Gruppe samlet. I referaterne ses ingen udtalelser af $H$. P. Hanssen, der kunne vise, hvordan han så på Det sønderjyske Venstre; men han var indforstået med den løsning, man nåede frem til. Der var vel ikke andet at gøre. Måske anså han ikke det grundlæggende for gruppen ændret. Partiets navn var ganske vist ændret, men som Hejmdal den følgende dag pointerede, forblev den en særlig sønderjysk valggruppe. ${ }^{35} \mathrm{H}$. P. Hanssen og Nis Nissen ville ikke blive bundet partipolitisk.

Blandt de delegerede var der en del, som kun vanskeligt kunne acceptere Det sønderjyske Venstre, og de havde stærkt kritiseret Thulstrup, fordi han indvirkede på afgørelsen. ${ }^{36}$ Flere udtalelser fra mødet viser, at de var skeptiske over for dansk partipolitik, specielt over for Venstre og dets grænsepolitik; det drejede sig frem for alt om at få valgt $\mathrm{H}$. P. Hanssen og Nis Nissen. Efter mødet skrev Th. 
Thomsen, Toghale, som var gået imod navnet *Venstre«, til H. P. Hanssen, at han ikke rigtig var tilfreds med resultatet af det. "Det blev en friergang til Venstre, hun er mig en noget kold jomfru, som jeg i grænsespørgsmålet ikke har megen sympati for, selv om jeg ellers ikke, så vidt jeg kender til den har noget at indvende imod Venstres almindelige politik, bare vi nu ikke henter os en kurv. ${ }^{37}$ Tilhængerne af en sønderjysk gruppe var altså ikke enige $i$ deres holdning til dansk partipolitik. En fløj bl. a. bestående af Anders Lebeck, I. H. Schmidt, Nis Nissen og Refslund Poulsen ønskede, at man foreløbig skulle indtage en mellemstilling mellem de radikale og venstrefløjen af Venstre. ${ }^{38}$

Den anden fløj, Refshauge og meningsfæller, har nok opfattet navnet og de forestående forhandlinger med Venstre som en tilstrækkelig garanti for, at de ikke gik ind $\mathrm{i} \rtimes$ tilsløret radikalisme«. Hvad Refshauge havde tænkt sig fremgår af en udtalelse til Dannevirke 15. sept. 1920: "Vi forsøgte så at danne Det sønderjyske Venstre, hvis navn angav en retningslinje for gruppen.*

Hverken i drøftelsen eller $i$ vedtagelsen af Det sønderjyske Venstre nævntes den trussel, som de nydannede Flensborg-venstreforeninger måtte være for det nye partis eksistens. Formodentlig gik deltagerne $i$ mødet ud fra, at Appel havde en vis opbakning $i$ Venstre. Den fremtrædende købmand og borgmester i Åbenrå, Holger Fink, oplyste senere, at han havde stemt for navnet Det sønderjyske Venstre $i$ fuld tillid til Appels udtalelse. ${ }^{39}$ Thulstrup synes $i$ hvert fald ikke $i$ tvivl og forudså ingen vanskeligheder. Han bad $i$ et telegram Appel sørge for, at der d. 28. juli i København kunne finde en forhandling sted mellem udvalget og venstrerepresentanter, der var forsynet med fuldmagt til at træffe bindende aftale. ${ }^{\mathbf{4 0}}$

Men netop samme dag d. 23. juli afholdtes et stort venstremøde i Sønderborg med ca. 200 deltagere. Heri deltog også to kongerigske venstrepolitikere som talere. Der nedsattes et udvalg med den opgave at få stiftet stærke venstreorganisationer i hvert eneste sogn på Als og Sundeved. ${ }^{41}$

Allerede d. 27. juli kunne J. C. Christensen meddele Neergaard, at en deputation bestående af bl. a. C. O. Pedersen, H. D. Kloppenborg-Skrumsager, Andr. Grau og Axel Sabroe, formanden for Dannevirkes tilsynsråd, ville komme til Kobenhavn og forhandle med Venstre d. 28. juli, altså samtidig med Det sønderjyske Venstre. ${ }^{42}$ Der 
er ikke fundet oplysninger om, hvornår og hvorfor Flensborggruppens Venstre nedsatte dette udvalg; men utvivlsomt kan det ses som en reaktion på Det sønderjyske Venstres beslutning.

Af den sønderjyske Venstrepresse tog Dybbøl-Posten straks afstand fra Det sønderjyske Venstre. Navnet kunne kun opfattes som en camouflage, der skulle gøre det muligt for partiet at placere sig mellem Venstre og de radikale på rigsdagen, whelst med bro til begge sider til brug efter behov “43 Dannevirke, der d. 1 . juli havde fået en kongerigsk venstreredaktør, stillede sig afventende, men mente ikke at oprettelsen af et nyt parti havde været nødvendig. ${ }^{44}$

Med vedtagelsen af Det sønderjyske Venstre opstod således den besynderlige situation, at der både skulle oprettes en selvstændig venstregruppe $\mathrm{i}$ alliance med Venstre, og samtidig hermed oprettedes venstreorganisationer med fuld tilslutning til Venstre. Venstre måtte nu åbent tage stilling. Hvis det gik ind på en ordning med Det sønderjyske Venstre og undlod at opstille kandidater i Sønderjylland, ville det blive skæbnesvangert for Flensborggruppens Venstre. På samme måde var Venstres holdning af afgørende betydning for Det sønderjyske Venstres vælgergrundlag og opretholdelse, idet det var blevet dannet under den forudsætning, at Venstre støttede det.

Efter Dannevirkes vurdering var også de kongerigske venstreblade gennemgående afventende. De fleste fandt dog den ny partidannelse uheldig med henblik på de bestående partiforhold på rigsdagen.45 $\mathrm{Da}$ imidlertid Venstres Pressebureau henvendte sig til J. C. Christensen for at høre hans mening, fik man et klart svar. Han tog bestemt afstand fra partidannelse. Tanken, om at alle sønderjyske rigsdagsmænd skulle danne en særlig gruppe på rigsdagen, var dermed bortfaldet. Ligeledes talen om en fælles front mod tyskerne. Nu ville man tværtimod straks danne politiske partier. Det sønderjyske Venstres program stemte efter J. C. Christensens mening overens med Venstres, men Venstre havde ikke delt sig i Jysk Venstre, Fynsk Venstre o.s.v., så hvis Det sonderjyske Venstre ville det samme som Venstre, ville det hurtigt opdage, at det var "kraftspild at stå som et lille parti på rigsdagen.« J. C. Christensen sluttede af med, at Venstre antagelig snart ville begynde valgarbejdet i Sønderjylland. ${ }^{46}$

Hvordan Venstre skulle forholde sig til de to deputationer, skrev 
J. C. Christensen om til Neergaard d. 27. juli. Efter hans skøn gjaldt det om, at begge deputationer fik et klart svar, som helst skulle udsendes gennem Ritzaus Bureau. Svaret skulle gå ud på, at ministeriet ikke kunne støtte Det sønderjyske Venstre, men måtte ønske, at vælgerne $\mathrm{i}$ de sønderjyske landsdele sluttede sig til Venstre og dets ministerium ved valgene uden forbehold. ${ }^{47}$

Også A. Grau henvendte sig til Neergaard. Fra allerbedste kilde havde han fået at vide, at flertallet af Det sonderjyske Venstre ville melde sig ind i Venstre, hvis Det sønderjyske Venstre ikke opnåede samarbejde med partiet. ${ }^{48}$

\section{FORHANDLINGER I AUGUST 1920}

\section{Venstres stillingtagen}

Den 3. august drøftede bestyrelsen for Venstre i begge rigsdagens ting, hvordan Venstre skulle stille sig til partidannelserne $i$ Sønderjylland. Statsminister Neergaard indledte med en redegørelse for nogle samtaler, der $\mathrm{i}$ de foregående dage var blevet fort mellem nogle ministre og repræsentanter for de sønderjyder, som ønskede opstillet kandidater i fuld tilslutning til Venstre. Deputationen fra Det sønderjyske Venstre ville i lobet af dagen søge forhandling med Venstres bestyrelse. ${ }^{1}$ Neergaard gjorde det klart, at der nu skulle træffes en beslutning, som kunne få vidtrækkende betydning. Der kunne formentlig regnes med stor sympati for Venstre i Sønderjylland. Spørgsmålet var så, om man skulle støtte de venstrekandidater, der opstilledes, eller om man skulle træde $\mathrm{i}$ forbindelse med Det sønderjyske Venstre. For Neergaard var der ingen tvivl. "Stilles der venstrekandidater op i de sønderjyske kredse, må vi støtte dem. Vil Det sønderjyske Venstre opretholde en selvstændig gruppe på rigsdagen, vil vi ikke kunne støtte det.« Undervisningsminister Appel meddelte derefter udfaldet af en samtale, han havde haft med Det sønderjyske Venstres deputation samme dags morgen. Han havde forklaret den, at valgloven udelukkede, at man både kunne støtte Venstre og samtidig optræde som selvstændigt parti, d.v.s. en klar afvisning af samarbejde. ${ }^{2}$ Hvordan og hvornår valgloven er kommet ind $\mathrm{i}$ billedet, fremgår ikke af materialet. Ud fra referatet ser det ud, som om begrundelsen med valgloven er indlysende og almindeligt bekendr, også 
af Appel. Om H. P. Hanssens reaktion herpå meddeles intet. Derimod presenteres et nyt forslag. Over for deputationens påstand om, at det var umuligt at forhandle med den anden venstregruppe hjemme i Sønderjylland, havde Appel oplyst, at netop denne gruppe havde tilbudt, "at man ville lade de sønderjyske kredse selv opstille de kandidater, der skulle være Venstres til valgene.« Ifølge Appel skulle H. P. Hanssen have erklæret, at $\mathrm{i}$ så fald forelå der en ny situation. "Hvis dette tilbud kunne konstateres, ville H. P. Hanssen arbejde for en overenskomst i den retning. $\kappa$

Efter denne orientering og en efterfølgende længere forhandling tilkaldtes den flensborgske delegation, som bekraftede, at Flensborggruppens Venstre var villig til at stotte den kandidat, som flertallet af venstrevælgere i hver kreds udpegede, også dem, der opstilledes uden for de af Flensborgretningen dannede organisationer, blot det var venstreorganisationer. Men det var et absolut krav, at Det sønderjyske Venstre opløstes; det kunne ikke anerkendes som en venstreorganisation. Derimod stod Venstres organisationer åbne for alle. Delegationen erklarede sig rede til forhandling med Det sønderjyske Venstre i København, hvis der viste sig mulighed for forståelse; men initiativet hertil måtte komme fra den anden part.

Denne tilbudte ordning kendes først på dette tidspunkt. Det ses ikke, hvilke venstrepolitikere der har haft kontakt med den flensborgske deputation, og hvem der har taget initativet til en sådan ordning; kun kan det konstateres, at Venstrerepræsentanter var $\mathrm{i}$ forbindelse med den flensborgske delegation inden forhandlingerne med Det sønderjyske Venstre. Ifølge ordlyden ville Flensborggruppens Venstre kunne anerkende venstreorganisationer, der var oprettet af Den nordslesvigske Gruppe og ville kunne støtte en kandidat fra denne gruppe, en betragtelig indrømmelse fra Flensborggruppens side. Til gengald måtte kravet om opløsning af Det sønderjyske Venstre anses som en alvorlig svækkelse for H. P. Hanssen og hans politik.

Kl. 1 samme dag modtog Venstres bestyrelse udvalget fra Det sønderjyske Venstre med $H$. P. Hanssen og Nis Nissen som ordførere. H. P. Hanssen udtalte, at udvalgets opgave bestod $i$ at høre betingelserne og vilkårene for et samarbejde med Venstre ved valgene. Opretholdelsen af en særlig gruppe ville få stor betydning derved, at den store gruppe af arbejdere, husmænd og håndværkere 
på landet endnu kunne fastholdes, mens byernes arbejdere ville gå ind i Socialdemokratiet. Formentlig var det også muligt at vinde en del af hjemmetyskerne. H. P. Hanssen søgte hermed at lokke Venstre til at støtte sig ved at stille det en stor tilslutning $\mathrm{i}$ udsigt; men hans argumentation gjorde ikke indtryk. Neergaard henviste til valglovens bestemmelser og til de allerede oprettede sønderjyske venstreorganisationer, som ville opstille kandidater $\mathrm{i}$ klar tilslutning til Venstre. Disse måtte man støtte af al evne. Venstre havde ikke ønsket at tage parti $\mathrm{i}$ de indre sønderjyske stridigheder, men nu, da indlemmelsen havde fundet sted, var det nødvendigt, at partiet agiterede dernede. De gamle nordslesvigske gruppeskel havde ikke noget med indre dansk politik at gøre.

H. P. Hanssen og Nis Nissen "takkede for de klare oplysninger «, og sidstnævnte bemærkede, at der altså kun var valget: at gå ind $\mathrm{i}$ Venstre eller lade være. Det forste fandt han meget vanskeligt. Mange arbejdere var stærkt radikaliserede og trængte til at få tid til at sunde sig, hvilket bedst skete gennem en særlig sønderjysk gruppe. "Havde man først stødt disse småkårsfolk fra sig, ville det være vanskeligt at vinde dem tilbage." Fra Venstre svaredes herpå, at partiet havde tilslutning $\mathrm{i}$ alle befolkningslag. Appel drejede derefter drøftelsen ind på Flensborggruppens tilbud; måske har han fornemmet en skarpere tone $\mathrm{i}$ replikskiftet. Om forslaget sagde $\mathrm{H}$. P. Hanssen, at det var kommet ret overraskende for dem, og at det ændrede situationen. For mit personlige vedkommende er der intet $i$ Venstres program, som kunne afbolde mig fra at $g a \mathfrak{a}$ ind $i$ Venstre, men vi mener at have en mission ved fastholdelsen af en særlig gruppe. Denne vor rejse er en informationsrejse, og vi har intet mandat til at træffe nogen beslutning. Vi skal forelægge de nye oplysninger for vor gruppe, der snarest skal tage stilling hertil.« Neergaard anså Venstre for at have de bedste betingelser for at samle i Sønderjylland, eftersom muligheden for at samle alle danske sønderjyder $i$ en gruppe ikke længere var til stede. $H$. P. Hanssen vurderede situationen således, at der sikkert inden for store kredse af Den nordslesvigske Gruppe ville være stærk tilslutning til en indmeldelse $i$ Venstre, mens der derimod $i$ andre kredse ville være modstand. Af Nis Nissen udtaltes det betydningsfulde $i$, at Flensborggruppen nu var villig til loyalt samarbejde. Han var sikker på, at mange af hans meningsfaller ville strække sig langt for at få afsluttet den bitre strid. En 
forhandling med den anden deputation endnu samme dag anså ordførerne ikke for ønskeligt. Den nordslesvigske Gruppe skulle først have lejlighed til at drøfte sagen. Men man havde intet imod at tage initiativ til en forhandling, og det foresloges, at representanter for Venstre deltog $i$ en sådan.

Drøftelsen afsluttedes med, at folketingsmand Brorsen udtalte sin glæde over forløbet af dagens forhandlinger, og H. P. Hanssen takkede "for den forstående modtagelse, han og hans venner havde fundet - hos Venstre. Hans gruppe ville nu i løbet af ca. en uge træffe en beslutning, som skulle blive meddelt Venstre.«

Senere på eftermiddagen afholdtes et fxllesmøde for Venstre i begge ting. Her vedtoges enstemmigt en henvendelse til befolkningen i Sønderjylland, hvori denne opfordredes til wat samle sig på Venstres frisindede og demokratiske grund, uanset de stridigheder, der hidtil har præget arbejdet dernede. Venstre og ministeriet vil kun kunne stotte de kandidater, der - opstillede af partiets nuværende og kommende organisationer - vil indmelde sig $\mathrm{i}$ Venstre på rigsdagen. $\kappa^{3}$ Henvendelsen udsendtes gennem Ritzaus Bureau.

Med denne udtalelse tog Venstre offentligt afstand fra Det sønderjyske Venstre, inden dets tillidsmand havde haft mulighed for en drøftelse i Ȧbenrå. H. P. Hanssen havde dog lovet et svar inden for en uge; men det anså Venstre åbenbart ikke for nødvendigt at vente på. Måske regnede man med, at forliget var i orden, hvilket Brorsens afsluttende bemærkning kunne tyde på. Det kunne også tænkes, at man med en klar udtalelse ville påvirke Den nordslesvigske Gruppes tillidsmænd inden mødet. Dertil kommer, at J. C. Christensen på et tidligt tidspunkt både offentligt og over for regeringen tog afstand fra H. P. Hanssens parti, hvilket kan have haft indflydelse på bestyrelsens beslutninger. Et fingerpeg herom kan det vere, at endog den af J. C. Christensen anviste fremgangsmåde blev benyttet. Endelig har en sådan henvendelse vel også haft betydning for Venstres flensborgske tilhængere i Sønderjylland.

De to sønderjyske venstreaviser Dannevirke og Dybbøl-Posten modtog meddelelsen om Venstres beslutning med tilfredshed. Dermed havde Venstre optrukket rene linjer for dets deltagelse i valgene i Sønderjylland og samtidig afklaret hele valgsituationen i landsdelen. Samarbejde på Venstres program var den bedste måde at udjævne grænsestridens modsætninger og til at samle sønderjyderne. De 
opfordrede kraftigt tilhængerne af Det sonderjyske Venstre til at slutte sig til Venstre. ${ }^{4}$

Den 7. august meddelte Dannevirke, at Venstres agitationsmøder ville blive påbegyndt d. 11. august, hvor Venstres rigsdagsmænd ville gøre rede for partiets program og politik. Ganske vist havde som tidligere nævnt to kongerigske venstrepolitikere deltaget i mødet i Sønderborg d. 23. juli; dette skyldtes muligvis Graus gentagne og indtrængende anmodninger til Neergaard om støtte i kampen mod H. P. Hanssens sønderjyske gruppe.

For Det sønderjyske Venstres representanter fik mødet med Venstre et andet udfald end forventet ved partiets dannelse. Hvordan reagerede H. P. Hanssen og Den nordslesvigske Gruppes meningsfaller på denne nye situation? Efter Appels udsagn havde H. P. Hanssen udtalt villighed til at arbejde for en overenskomst som foreslået af Flensborggruppen. Af referatet af selve forhandlingen med Venstres bestyrelse fremgår imidlertid H. P. Hanssens holdning ikke helt så klart. Han udtalte sig positivt om tilbudet og ville fremlægge det for gruppen; men han gav ingen lofter om indmeldelse i Venstre. H. P. Hanssens og Nis Nissens ihærdige argumentation for en særlig gruppe viser, at dette var deres ærinde. Desuden kom de, især Nis Nissen, med nogle spidse bemærkninger mod Venstre og Flensborggruppen. Samtidig udtalte de imidlertid begge vilje til at samarbejde med den anden gruppe og takkede Venstre ved mødets slutning. Hvordan H. P. Hanssens tonefald så har været, da han takkede, kan ikke afleses af referatet.

Fra dagene efter modet er der ikke fremkommet udtalelser af $\mathrm{H}$. P. Hanssen, som direkte kunne vise, hvor han stod. Af et brev fra Thulstrup til Appel d. 21. august fremgår det, at disse to havde en samtale efter $d$. 3. eller d. 4. august. Thulstrup havde da fortalt Appel, at han havde indtryk af, at H. P. Hanssen og Nis Nissen var villige til at gå ind på den foreslåede ordning. D. 21. august påstod Thulstrup, at hans formodning var rigtig på daværende tidspunkt, for H. P. Hanssen havde om aftenen d. 3. august over for Nis Nissen, Thulstrup og hans kxreste udtalt sig på en sådan måde, at de alle havde fået bestemt indtryk heraf. Sådan havde også Refslund Poulsen og de to andre medlemmer af deputationen opfattet $H$. P. Hanssens holdning. Den folgende dag havde H. P. Hanssen, stadig ifølge Thulstrup, udtalt det samme over for Lebeck i Haderslev. Om 
aftenen havde $H$. P. Hanssen en konference med brødrene Holger og Olav Fink. Efter denne slog han om og ville gå ud af aktiv politik. 5

Lebeck og H. P. Hanssen havde ganske rigtigt talt sammen d. 4. august og drøftet situationen, hvilket ses af et brev fra Lebeck til H. P. Hanssen den følgende dag. Heri skrev Lebeck, at han trods alt anså samarbejdet med Venstre for det vigtigste for H. P. Hanssen og Nis Nissen. Et valg mod Venstre ville, sådan som forholdene lå, ikke være muligt. Lebeck selv ville dog holde sig passiv; han kunne ikke agitere for Venstre sammen med Axel Sabroe, M. Strandskov Nøhr, redaktøren ved Dannevirke, og C. O. Pedersen, som i Venstres navn havde bundet hans ytringsfrihed. ${ }^{6}$ Et par af Lebecks artikler om en særlig sønderjysk gruppe var som nævnt $i$ juli blevet stoppet af Dannevirkes ledelse, hvilket havde vakt stor vrede blandt Lebecks meningsfæller. ${ }^{7}$

\section{Opløsningen af Det sønderjyske Venstre}

Udvalget vendte tilbage fra Kobenhavn d. 4. august, og dagen efter kunne Hejmdal meddele, at Det sønderjyske Venstres tillidsmænd var indkaldt til møde d. 10. Der var under forhandlingerne fremkommet oplysninger, der havde skabt en ny situation, som tillidsmændene skulle tage stilling til. ${ }^{8}$ Hejmdal refererede, hvad der var sket, men tog ikke stilling. D. 6. august antydedes dog Det sønderjyske Venstres skæbne: *Tiden vil vise, at der $\mathrm{i}$ overgangstiden er en særlig national mission at løse for en sønderjysk valggruppe, og det vil hævne sig, hvis den umuliggøres. « 9

D. 10. august samledes Det sønderjyske Venstres ca. 300 tillidsmænd fra alle egne af Nordslesvig til møde i Ảbenrå for at tage stilling til resultatet af forhandlingerne i København. H. P. Hanssen indledte med at afgive en beretning om forhandlingerne. Han og Nis Nissen var blevet stillet over for en ny situation, og efter at have talt med venner og meningsfaller var de blevet enige om et standpunkt. H. P. Hanssen oplæste derefter en erklæring på Nissens og egne vegne. Heri ridsedes situationen op, som den så ud for det sønderjyske Venstre. De forudsætninger, under hvilke partiet var dannet, fandtes ikke længere. Et samarbejde med Venstre måtte betragtes som udelukket, medmindre gruppen fraveg sit principielle standpunkt, opløste sig og gik fuldstændig op i Venstre. Foruden de kon- 
servative og socialdemokraterne ville også Venstre opstille kandidater i Sønderjylland, hvilket var ensbetydende med en alvorlig konkurrent for Det sønderjyske Venstre. Mens gruppens mål havde været »frugtbart nationalt arbejde«, stod den nu "i fare for at blive trængt ud $i$ en gold politisk partikamp.* Videre hed det, at tilbudet fra Flensborggruppen om samarbejde på Venstres program desuden kunne accepteres af en del af $\mathrm{H}$. P. Hanssens egne meningsf $x$ ller i grænsespørgsmålet. På baggrund heraf ønskede $\mathrm{H}$. P. Hanssen og Nis Nissen ikke, at deres personer skulle stå som en hindring for et sådant samarbejde, og de anbefalede derfor Det sønderjyske Venstres opløsning. I overensstemmelse med deres tidligere udtalelser ville de blive stående uden for partierne og ikke lade sig opstille ved valget. Nis Nissen føjede til erklæringen, at denne beslutning ikke var faldet dem helt let, men den stod fast. Han bad mødedeltagerne afkorte diskussionen; der kunne måske falde bitre ord, som det var bedre at undgå.

Diskussionen efter erklæringen blev et bittert opgør mellem tilhængere og modstandere af en særlig sønderjysk gruppe. J. H. Schmidt mente ikke, at arbejderne, der havde være med til at danne en sønderjysk gruppe, ville gå ind i Venstre. Eftersom det havde vist sig, at den opfattelse, Appel havde givet udtryk for, ikke var Venstres, ville han foreslå, at de blev stående som gruppe og sendte $H$. P. Hanssen og Nis Nissen ind på den danske rigsdag. "Vi vil slutte op om H. P. Hanssen. Hold fast ved en sønderjysk gruppe. « I de følgende indlxg beklagedes, at man var havnet $i$ en så uheldig situation. Eksempelvis kan citeres Refslund Poulsens udtalelse: »De, der er skyld $\mathrm{i}$ det, må føle sig forpligtet til at få folk - vi vil ikke hjxlpe ud af det.« Nissen konstaterede, at man ikke havde villet tro på deres ord om, at de ikke ville ind i noget parti, og Olav Fink ville ikke indmelde sig $\mathrm{i}$ Venstre efter den illoyale måde, partiet havde behandlet dem på. Repræsentanter fra Haderslev østeramt mente derimod, at det var rigtigst at gå ind i partierne; men dermed underkendte de ikke H. P. Hanssen og hans grænsepolitik. Modstanderne fra østeramtet støttedes af Mads Gram fra vesteramtet. "Begravelsesluft $\mathrm{i}$ dag utiltalende, $\mathrm{Ny}$ tid, vi oplever - bedst at dele os efter kongerigske partier. ${ }^{10}$

Ifølge Hejmdals referat ${ }^{11}$ havde tilhængerne beklaget, at nogle af gruppens medlemmer, der havde arbejdet for Det sønderjyske Ven- 
stres oprettelse, havde forhandlet på egen hånd uden om udvalget. Det antydes her, at gruppen ikke har stået samlet udadtil alligevel eller måske snarere, som en tillidsmand udtrykte det, at der har været tale om et "grundskud fra vore egne rækker. ${ }^{12}$ Et notat af Lebeck, om at Refshauge vistnok havde svært ved at stå for smiger fra Venstres side, kan måske give et fingerpeg om, at Refshauge havde været $\mathrm{i}$ kontakt med Venstre. ${ }^{13}$ I et andet indlæg blev det sagt, at nogle havde »taget større hensyn til stands- og særinteresser end til fædrelandets tarv." Refshauge følte sig åbenbart ramt: "Vi vil ikke særinteresser. Andre har skyld end vi i Haderslev østeramt. «14 Forholdet til H. P. Hanssen og Venstre har sikkert stillet Refshauge i et dilemma, og han opfordrede H. P. Hanssen til eventuelt at stille sig som løsgænger, hvad denne nægtede..$^{15}$

Også mod Venstre rettedes beskyldninger. Venstre var svinget bort fra Appels løfte, og dets fører havde svigtet Den nordslesvigske Gruppe.

Efter Refshauges vurdering havde H. P. Hanssen været bestemt og kort for hovedet, ${ }^{16}$ og ud fra Lebecks fragmentariske noter spores en vis bitterhed hos $\mathrm{H}$. P. Hanssen $\mathrm{i}$ hans afsluttende kommentar. Han anbefalede kun modvilligt opløsningen af Det sønderjyske Venstre. »Almindelig glidning som i grænsespørgsmålet - sådan også her. Frafald som følge af forhandlinger med Venstre ... Ikke føre valgkamp: "Mdm.« [Modermålet] imod os, »Dbp.« [Dybbøl-Posten] imod os - tre store partier imod os; klistre os sammen med de radikale. Det vil vi ikke. « Efter at have konstateret, at Appels og Madsen-Mygdals tilbud altså ikke holdt stik, udtrykte H. P. Hanssen en stærk kritik af venstreregeringens sønderjyske politik, og opfordrede de meningsfæller, der straks meldte sig ind $\mathrm{i}$ Venstre, til at sørge for, at de bedste mænd kom ind på rigsdagen. ${ }^{17}$

Forslaget om opløsning af Det sønderjyske Venstre vedtoges enstemmigt, hvilket $\mathrm{H}$. P. Hanssen den falgende dag kort meddelte Neergaard. ${ }^{18}$

Selv om H. P. Hanssen helst havde set en opretholdelse af en særlig sønderjysk gruppe, anbefalede han Det sønderjyske Venstres opløsning, dels fordi partiet ikke kunne holde Den nordslesvigske Gruppe samlet, dels fordi en valgkamp mod tre partier, specielt mod Venstre, vanskeligt kunne lade sig gøre. Et samarbejde med Flensborg- 
gruppen på Venstres program havde været på tale; men H. P. Hanssen foretrak at holde sig uden for aktiv politik. I denne forbindelse kunne man spørge, om $\mathrm{H}$. P. Hanssen havde overvejet at træde ind i Venstre og i bekræftende fald, hvorfor han ikke gjorde det?

Thulstrup var tydeligt chokeret over den vending, sagen havde taget, og som han skrev til Appel, havde han tit fortrudt, at han på mødet d. 23. juli havde refereret sine private samtaler med Appel.19 Både Thulstrup og Refshauge påstår, at H. P. Hanssen umiddelbart efter mødet med Venstre og også ved hjemkomsten havde været tilfreds med resultatet og ville gå med til den foreslåede ordning. ${ }^{20}$ De kan have lagt for meget i H. P. Hanssens omtale af forhandlingen. I betragtning af den stærke kritik, der blev rejst imod dem efter opløsningsmødet for deres medvirken, kunne deres fremhævelse bagefter af $\mathrm{H}$. P. Hanssens villighed opfattes som et forsvar for deres handlemåde. For Thulstrup har det vel også spillet en rolle, at han var så stærkt engageret $i$ bestræbelserne på at finde frem til en ordning. Han kan have tolket H. P. Hanssens udtalelser, sådan som han selv ønskede dem.

På den anden side nævnte Thulstrup navne på personer, han havde talt med, og som altså skulle have fået samme indtryk som Thulstrup. Desuden tyder Lebecks brev på, at han og H. P. Hanssen havde drøftet både muligheden af at gå til valg på en særlig sønderjysk gruppe og at melde sig ind $\mathrm{i}$ Venstre. Lebeck rådede ham bagefter til at søge samarbejde med Venstre. Det anses derfor ikke for utænkeligt, at $\mathrm{H}$. P. Hanssen kan have overvejet muligheden heraf. Han kunne vel have opnået en vis selvstændig position inden for Venstre ved at arbejde for, at hans meningsfxller $i$ stort tal meldte sig ind $i$ venstreorganisationerne og besatte de ledende poster eller måske ved at oprette Ảbenråorienterede venstreforeninger.

H. P. Hanssen rådførte sig imidlertid også med andre meningsfaller. Thulstrup var ikke i tvivl om, at brødrene Fink havde haft afgørende indflydelse på H. P. Hanssens beslutning. Han formodede, at Olav Fink havde bearbejdet H. P. Hanssen med, at han ved at acceptere en sådan ordning siden ville blive gjort ansvarlig for hele Venstres sønderjyske politik og havde gjort ham opmærksom på frafaldet inden for selve gruppen. ${ }^{21}$ D. 10 . august omtalte H. P. Hanssen selv et frafald som følge af forhandlinger med Venstre. Et sådant 
synes ikke usandsynligt, når det erindres, hvilke betænkeligheder en del af medlemmerne gav udtryk for over for Venstre på mødet d. 23. juli. Olav Fink ville ikke ind i Venstre, og H. P. Hanssen skulle have udtalt til Lebeck, at Finks beslutning bl. a. var det, der gav det endelige stød til hans tilbagetræden.22

Det ville vel også være vanskeligt for $H$. P. Hanssen efter de hårde angreb at skulle føre valgkamp sammen med Flensborggruppens Venstre, måske tvivlede han på gruppens loyalitet. Han havde jo fulgt udviklingen ved venstrebladet Dannevirke, hvor tilsynsrådets "flensborgske flertal søgte at begrænse Den nordslesvigske Gruppes indflydelse, specielt Lebecks.

Endelig kan det ikke udelukkes, at Venstres henvendelse til den sønderjyske befolkning har påvirket $H$. P. Hanssen. Denne måde offentligt at afvise samarbejde med $H$. P. Hanssens gruppe kunne have virket sårende på $\mathrm{H}$. P. Hanssen. Ud fra flere beskrivelser af H. P. Hanssens kone, Helene Hanssen, ville det ikke være utænkeligt, om hun har bestyrket ham $i$ hans beslutning. Hun stod skarpt over for Venstre, og i særdeleshed kunne hun ikke lide J. C. Christensen. ${ }^{23}$

\section{Venstrepolitikeres reaktion på mødet}

Dagen efter opløsningsmødet udsendte Appel og Madsen-Mygdal en erklæring, hvori de oplyste, at de under den private samtale med H. P. Hanssen d. 10. juli stærkt havde fremhæret onsket om, at der optoges en forhandling med Venstre inden tillidsmandsmødet d. 23. juli. Desuden havde de betonet, at Venstre måtte støtte de kandidater, der blev opstillet i tilslutning til Venstre. Hejmdal kommenterede erklæringen således, at der ikke var noget positivt urigtig i den; men de to politikeres udtalelser til H. P. Hanssen og andre inden for gruppen var blevet opfattet som et tilsagn fra Venstre. ${ }^{24}$

Med denne erklæring gjorde Appel sin stilling til Venstre og Det sønderjyske Venstre klar. Hans holdning indtil da forekommer umiddelbart ret tvetydig. Hvad han og Madsen-Mygdal prxcis sagde til H. P. Hanssen d. 10. juli kan ikke efterspores, derimod kan Thulstrups breve til Appel nxppe tolkes på anden måde, end at Appel har givet visse forhåbninger, måske endda tilsagn om en ordning med Venstre. Da deputationen fra Det sønderjyske Venstre mødte til forhandling med Venstre, var det netop Appel, der meddelte, at 


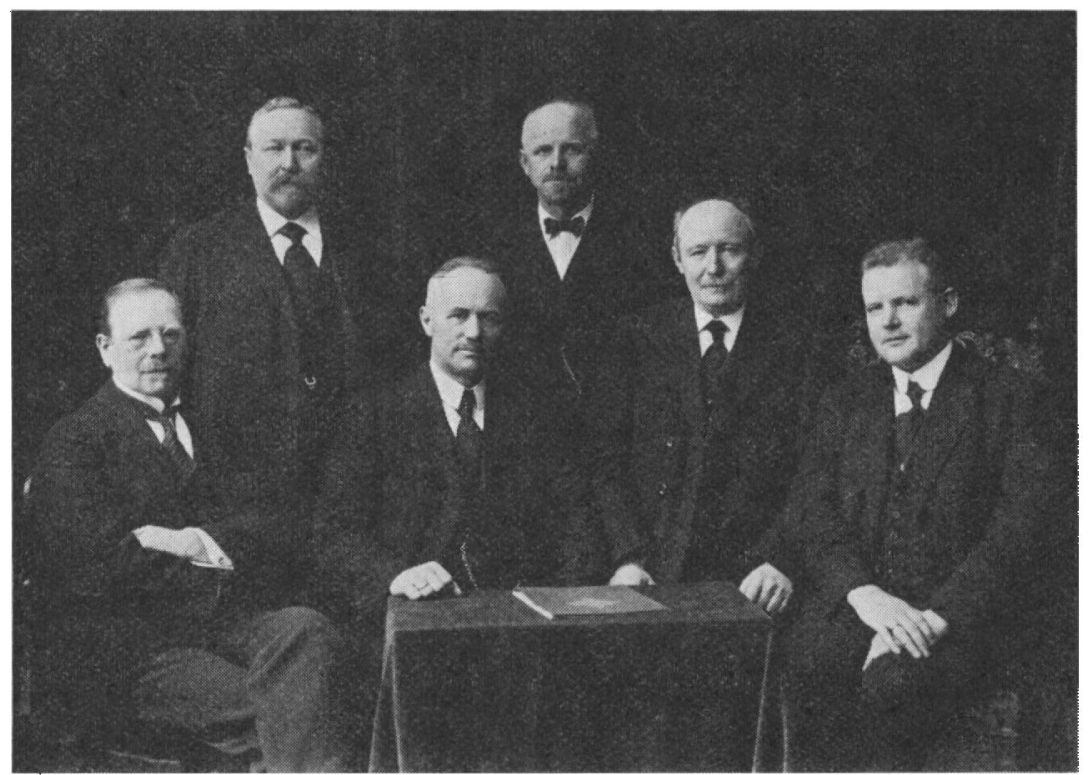

Ved det forste rigsdagsvalg efter genforeningen fik Venstre syv mandater $i$ Nordslesvig. Mens de fire folketingsmend alle tilhørte Abenrd-retningen, blev Flensborg-venstre representeret $i$ Landstinget af $H$. D. Kloppenborg-Skrumsager, som ikke er med pà billedet. Fra venstre ses folketingsmendene Anders Lebeck, Cbristen Ernst Christensen, $P$. J. Refshauge og Mads Gram, samt landstingsmendene H. Jefsen Christensen og Andreas Karberg. (Historiske Samlinger for Sonderiylland)

en ordning på grundlag af Det sønderjyske Venstre ikke kunne lade sig gøre. Efter referaterne at dømme berørtes end ikke Appels forbindelse med Det sønderjyske Venstre. Endelig udsendtes så erklæringen d. 12. august.

Som en forklaring på Appels optræden kunne man fremdrage hans stilling: han var minister $i$ en venstreregering og var samtidig sønderjyde og tilhænger af H. P. Hanssens politik. Ved regeringsdannelsen $i$ maj ville han $f$. eks. ikke tage imod en ministerpost uden forudgående drøftelse med $\mathrm{H}$. P. Hanssen, da han ikke onskede et brud med denne. Desuden viste han sig både $\mathrm{i}$ maj og juli meget interesseret $i$ at få en forståelse $i$ stand mellem Venstre og H. P. Hanssen, at få knyttet H. P. Hanssen til Venstre.

$\mathrm{Da} H$. P. Hanssen søgte at realisere sin sønderjyske valggruppe, måtte Appel som venstremand tage afstand fra den; men samtidig 
søgte han at vende gruppen over mod Venstre. Da han d. 3. august på Venstres vegne afviste Det sønderjyske Venstre med henvisning til valgloven, lød det, som om denne regel ikke var fremmed for ham; måske har han ikke $i$ juli nøjere tænkt på, hvordan en sønderjysk gruppe $i$ alliance med Venstre kunne gennemføres i praksis, eller måske havde han ikke forestillet sig, at Det sønderjyske Venstre skulle være et selvstændigt parti, men at det skulle støtte Venstre. Det væsentligste var vel at få en dialog $i$ gang mellem Venstre og Den nordslesvigske Gruppe og få afværget sønderjysk særpolitik. Måske har Appel ligesom tidligere forsøgt mæglerens rolle for at undgå et brud mellem H. P. Hanssen og Venstre.

Også J. C. Christensen kommenterede H. P. Hanssens oplysninger på Åbenråmødet d. 10 august: »Jeg har ikke forhandlet med nogen og ikke lovet nogen noget, og jeg kan derfor intet sige. ${ }^{25}$

\section{SAMMENFATNING}

Tanken bag det oprindelige forslag var, at en sønderjysk valggruppe så vidt mulig skulle repræsentere hele den sønderjyske befolkning; men som det viste sig, kunne det ikke lade sig gøre i 1920 . Heller ikke en snævrere gruppe, Den sønderjyske Gruppe/Det sønderjyske Venstre, lod sig gennemføre. Hvilke motiver havde H. P. Hanssen til at foretrække en sønderjysk valggruppe, og hvorfor mislykkedes planen?

At H. P. Hanssen skulle have onsket en sønderjysk gruppe af personlige hensyn for dermed at få garanti for selv at blive valgt ind på rigsdagen, afvises endog af det flensborgsindede tidsskrift Grænsevagten som meningsløs. $H$. $P$. Hanssen ville altid være sikker på at blive valgt. ${ }^{1}$

H. P. Hanssen havde fra sin ungdom beskæftiget sig med sønderjysk politik, og ifølge egne udtalelser var det især løsningen af de sønderjyske spørgsmål, der optog ham ved genforeningen. »Indre danske småting " var han ikke interesseret i at arbejde med. De sønderjyske spørgsmål løstes bedst af sønderjyderne selv, da de havde mest kendskab til forholdene. Dette trenkte han sig kunne ske gennem en samlet sønderjysk repræsentation på den danske rigsdag. Det var de praktiske spørgsmål $\mathrm{i}$ forbindelse med genforeningen, der skulle holde gruppen sammen, således at der blev ført en sønderjysk 
politik, der var i overensstemmelse med sønderjyske interesser uden partipolitisk indblanding.

Ud fra en vurdering af de sønderjyske forhold talte ifølge $H . P$. Hanssen også meget andet for dannelsen af en særlig gruppe, bl. a. sønderjydernes ukendskab til dansk partipolitik, fastholdelsen af småkårsstanden og samling mod tyskheden.

Derudover kunne nogle udtalelser tyde på, at H. P. Hanssen regnede med, at gruppen kunne få en vis position på rigsdagen. Han nævnte $i$ april muligheden af, at gruppen kunne blive tungen på vægtskålen, derimod udtalte han det modsatte $\mathrm{i}$ juli. Her må det tages $\mathrm{i}$ betragtning, at situationen da var en ganske anden, idet H. P. Hanssen her stod over for meningsfaller, som var modstandere af en uafhængig gruppe med selvstændig rolle. Desuden havde valget i april forrykket styrkeforholdet mellem partierne.

Tillige synes gruppen tiltænkt en vis mission på rigsdagen ved, som det hed, at lære partierne at samarbejde og tænke mere på fædrelandets vel end på partitaktiske manøvrer. En sønderjysk gruppe skulle ikke have nogen bestemt partipolitisk tilknytning, men samarbejde med alle partier. Selv var H. P. Hanssen ikke interesseret i at blive bundet af partipolitiske hensyn, hvilket han fastholdt indtil Det sønderjyske Venstres forlis. Man kunne henvise til en politisk parole, som H. P. Hanssen ofte gentog både før og efter 1920, og som lød: "Vi er et folk, ikke et parti. « ${ }^{2}$

Om der ligefrem gennem en sonderjysk gruppe tilstræbtes en politisk genforening mellem Venstre og Det radikale Venstre, som Dybbøl-Posten antydede og Grænsevagten påstod, kan vanskeligt afgøres på det foreliggende materiale. Ifølge Grænsevagten skulle redaktøren ved Hejmdal, Niels Hansen, året før have udtalt, at det var en passende opgave for sønderjyderne at genforene disse skilte elementer. Tidsskriftet konkluderede, at »brobygningsplanen « sikkert har ligget bag H. P. Hanssens og Nis Nissens forestillinger om gruppens fremtidsprogram. "Det nye parti skulle nærme parterne til hinanden, indtil de radikale på ny kunne gå op $i$ Venstre, derved at Venstre selv lod sig radikalisere. ${ }^{3}$

Lebeck og andre var åbenbart ikke fremmed over for tanker, der gik i samme retning Helt klart fremgår det af et brev, som Lebeck ganske vist først skrev i 1921: »Jeg betragter det ikke som udelukket, at som Venstre før har været ét, vil det kunne blive ét igen. «4 
Derimod synes der ikke at kunne udledes noget om $\mathrm{H}$. P. Hanssens standpunkt herom.

Den nordslesvigske Gruppe havde skilt sig ud på grundlag af fælles grænsepolitisk syn; da partiorganisationsspørgsmålet blev bragt på bane, splittedes gruppen $i$ to fløje. Generelt var der sympati for Venstres program i gruppen. Også $\mathrm{H}$. P. Hanssen var venstremand, men besluttede at stille sig uden for partierne. For det første foretrak han dannelsen af en sønderjysk gruppe, og for det andet kunne han ikke melde sig ind i Venstre på grund af dets grænsepolitik. Dertil kom desavoueringen af $H$. P. Hanssen ved regeringsdannelsen i maj og det voksende modsæetningsforhold mellem $H$. P. Hanssen og Venstre og især mellem førstnæunte og J. C. Christensen, hvilket nok væsentligt har bidraget til H. P. Hanssens fastholdelse af tanken i 1920. Mange, deriblandt Lebeck, J. H. Schmidt, Refslund Poulsen og Nis Nissen, støttede ubetinget $\mathrm{H}$. P. Hanssen, - han var jo den ubestridte politiske fører under fremmedherredømmet. Partipolitik var i den forbindelse underordnet. For andre bl. a. Refshauge og Gram var det derimod vasentligt at få klarlagt gruppens partipolitiske standpunkt. De frygtede en tilknytning til Det radikale Venstre, hvad de ikke kunne acceptere. I grunden ønskede de helst en politisk organisering på linje med kongerigets og ville i samarbejde med Flensborggruppen slutte sig til Venstre. En sønderjysk gruppe ville ikke bidrage til at slette grænsestridens modsætninger. Alligevel gik de med til en gruppe, hvor et kongerigsk partinavn kom med i navnet. H. P. Hanssen og flere med ham kunne tilslutte sig dette, mens andre ikke kunne acceptere forhandling med Venstre. $\mathrm{Da}$ Venstres stilling og Flensborggruppens tilbud var meddelt dem, delte gruppen sig. D.v.s. at uanset, hvad H. P. Hanssen gjorde, ville Den nordslesvigske Gruppe blive splittet, idet nogle prioriterede det sønderyske og grænsespørgsmålet, mens andre prioriterede det partipolitiske. H. P. Hanssen valgte at forholde sig passiv, ligesom Lebeck havde sagt, at han ville. Som foreslàet kunne han have stillet sig som løsgænger, men han afslog, sikkert fordi han derved ville komme til at stå alene på rigsdagen og ikke med en samlet sønderjysk repræsentation bag sig.

Flensborggruppen kunne i 1920 ikke støtte en sønderjysk gruppe, som var foreslået og forberedt af $H$. P. Hanssen og udgået fra Den 
nordslesvigske Gruppe. Dertil var modsætningerne alt for store man kunne under ingen omstændigheder være med til bagefter at godkende H. P. Hanssens grænsepolitik og hans indtræden i det forhadte radikale ministerium. Grænsevagten skrev $\mathrm{i}$ august 1920, at H. P. Hanssens mministerudnæwnelse gjorde skellene i Sønderjylland så dybe, at han for al fremtid mistede sin stilling som samlende fører «. Han havde muligvis evnet at realisere tanken om en sønderjysk gruppe i 1918, men spildte enhver mulighed for det ved at gå ind i en partiregering. Hensynet til hans kolleger $i$ regeringen havde bundet ham på for mange måder. ${ }^{5}$ Under grænsestriden havde Flensborggruppen haft kontakt med oppositionspartierne; man vidste udmærket, hvilke partier man sympatiserede med. Flensborggruppens venstrefolk, bl. a. dyrlæge C. O. Pedersen, Andr. Grau og H. D. Kloppenborg-Skrumsager, begyndte hurtigt at agitere for dannelsen af venstreforeninger. Man ønskede fuld tilslutning til kongerigets Venstre og forsøgte gang på gang at få partiets tilsagn om støtte.

Som næunt viste Den nordslesvigske Gruppes meningsfæller på møder stor interesse for Venstre. Også blandt Flensborgfolkene var der tilslutning til partiet. Venstre kunne sikkert forvente at få stor tilslutning i Sønderjylland; men H. P. Hanssens forsøg på at danne en sønderjysk gruppe samtidig med, at Flensborggruppen oprettede venstreforeninger, måtte vanskeliggøre partiets muligheder. Problemet for Venstre bestod $i$, at partiet havde tilhængere $i$ både Flensborggruppen og Den nordslesvigske Gruppe. På den ene side stod H. P. Hanssen, som utvivlsomt ville blive fulgt af mange tilhængere, således at en sønderjysk gruppe kunne blive en alvorlig konkurrent for Venstre. $\mathrm{På}$ den anden side stod de af Flensborggruppen oprettede venstreforeninger. Herfra fremhævedes det, at hvis Venstre forholdt sig passiv, ville de konservative og Den nordslesvigske Gruppe tage stemmerne. Venstre valgte $\mathrm{i}$ juni at forholde sig afventende, sikkert ud fra den betragtning, at hvis sønderjyderne selv kunne ordne partiforholdene, behøvede Venstre ikke at tage parti og kunne derved undgå modsætningsforhold til de to grupper.

Med beslutningen om dannelsen af Det sønderjyske Venstre blev Venstre direkte draget ind i sønderjysk partipolitik. Neergaards udtalelse, om at der skulle træffes en beslutning af vidtrakkende betydning, kunne tyde på, at Venstres organisation i Sønderjylland 
blev anset for at være af stor vigtighed for partiet. Man var enige om et afslag til H. P. Hanssen. Venstre kunne ikke desavouere de sønderjyske venstreforeninger; men også andre forhold kan have påvirket Venstres holdning. Partiet har muligvis frygtet en svakkelse i forholdet til de andre partier, hvis det ikke selv straks fik fodfæeste i Sønderjylland. Desuden havde man fra Grau fået at vide, at flertallet af Det sønderjyske Venstre ville slutte sig til Venstre, hvis det ikke opnåede samarbejde med Venstre. Indadtil kunne man forestille sig, at en sønderjysk venstregruppe muligvis kunne optræde som en splittelsesgruppe, og derved skabe indre brydninger. Endelig ville en sådan særlig gruppe kunne svække enheden inden for partiet. Venstre var ikke opdelt i landsdelspartier.

I den periode, hvor Venstres forhold til sønderjysk partipolitik afklaredes, aftegnede der sig forskellige fløje inden for partiet. Som nævnt var der stort set enighed om at tage afstand fra sønderjysk særpolitik; derimod var der divergerende opfattelser af $\mathrm{H}$. P. Hanssen og den holdning, Venstre skulle indtage over for ham. Mens politikere som Madsen-Mygdal og Appel syntes meget interesseret $i$ at få draget H. P. Hanssen og hans meningsfaller ind $\mathrm{i}$ et samarbejde med Venstre, var det modsatte tilfældet med J. C. Christensen. Han var meget afvisende over for $H$. P. Hanssen, hvilket nok bundede $i$ H. P. Hanssens optagelse $i$ den radikale regering, hvorved han havde bremset Venstre. Af begivenhedsforløbet ses det, at J. C. Christensen i høj grad udnyttede den position, han havde $i$ partiet til at få indflydelse på regeringens politik. Han udtalte sig bl. a. offentligt om henholdsvis Den sønderjyske Gruppe og Det sønderjyske Venstre, inden den samlede regering offentligt havde taget stilling, og han gav Neergaard direktiver m.h.t. de to sonderjyske deputationer.

Med opløsningen af Det sønderjyske Venstre var partiforholdene blevet afklaret; Sønderjylland skulle organiseres efter de samme linjer som i det øvrige land. Mange tilhængere af Det sønderjyske Venstre meldte sig ind $\mathrm{i}$ Venstre; men dermed var modsxtningerne ikke bilagt. I en skriftlig overenskomst delte Ảbenrå- og Flensborgretningen i partiet de syv opstillingskredse mellem sig inden valget d. 21. sept. 1920. Ved valget blev Venstre det sejrende parti og fik fire kredsmandater ud af syv. De fire kandidater Ảbenråvenstre havde opstillet blev valgt (Mads Gram, Anders Lebeck, Chr. E. Christensen og 
P. J. Refshauge), hvorimod Flensborgvenstre ikke blev repræsenteret. Dermed var kimen lagt til fortsat modsætningsforhold i de følgende år.

\section{KILDER OG LITTERATUR}

\section{Utrykte kilder}

Landsarkivet for de sønderjyske landsdele, Abenrå:

Vxlgerforeningen for Nordslesvig: 1908-21. Forhandlingsprotokol for bestyrelses- og tilsynsrådsmøder. 1920. Forhandlingsprotokol for Den nordslesvigske Gruppe. (Niels Hansen).

De samvirkende Venstreforeninger i Sønderjylland: Forhandlingsprotokol 1924-32.

Chr. E. Christensens arkiv: Sager vedr. folketingsvalgene 1924, 1929, 1932, landstingsvalget 1928 og partiet Venstre. Breve fra forskellige. Forskelligt. Sager vedr. Dybbel-Posten.

Mads K. Grams arkiv: Breve fra forskellige.

H. P. Hanssens arkiv: Optegnelser til foredrag, kronologisk ordnet. Korrespondancesager vedr. $H$. P. Hanssens virksomhed som dansk rigsdagsmand. Breve fra forskellige.

H. D. Kloppenborg-Skrumsagers arkiv: Sager vedr. virksomheden som landstingsmand. Breve fra forskellige.

Anders Lebecks arkiv: 1918-21. Optegnelser under verdenskrigen. 192325. Optegnelser sommeren 1923, fortsat sommeren 1924, fortsat og sluttet 1925. 1923. Korrespondance isxer vedr. Modersmálet. 1918-20. Referater af Vxlgerforeningens moder. Breve fra forskellige.

Nis Chr. Nissens arkiv: Breve fra forskellige.

Niels Skrumsager arkiv: Sager vedr. folketingsvalget 1924.

Andreas Thulstrups arkiv: Breve og program for Den sønderjyske Gruppe. J. H. Schmidts arkiv: Breve fra forskellige.

\section{Rigsarkivet, Kobenhavn:}

Venstres arkiv: Forhandlingsprotokoller for rigsdagsgruppernes fællesmøder 1917-24.

Niels Neergaards arkiv: Bind 8. Politiske optegnelser. 30. okt. 1912-26. juli 1920. Breve fra forskellige.

Jacob Appels arkiv: Breve.

Trykte kilder og litteratur

Oluf Bertolt, Ernst Christiansen og Poul Hansen: En bygning vi rejser. II. 1955.

Bladet *Dannevirke* 1838-1938. 1938.

Bogen om H. P. Hanssen. 1948.

Bogen om J. C. Christensen. 1941.

L. P. Christensen: Slesvig delt. 1922.

Dannevirke-Modersmålet 1920.

Den danske rigsdag 1849-1949. 1951.

Dybbøl-Posten 1920. 
Troels Fink: Den parlamentariske basis for H. P. Hanssen som medlem af ministeriet Zahle. (Historie XI, 4, 1976 s. 429-492).

Troels Fink: Rids af Sønderjyllands historie. 1946.

Troels Fink: Sonderjylland siden genforeningen i 1920. 1955.

N. J. Gotthardsen: På vagt for Danmark. 1946.

Mads K. Gram og P. J. Refshauge: Striden om "Dannevirke«. 1923.

Grænsen. Statsradiofoniens grundbog. 1955.

Grænsevagten 1919-20.

H. P. Hanssen: Dagbogsoptegnelser november og december 1918.

H. P. Hanssen: Et tilbageblik. I-IV. 1930-34.

H. P. Hanssen: Fra kampårene. I-II. 1927-29.

H. P. Hanssen: Fra krigstiden. I-II. 1924.

Hejmdal 1920.

Peter Kr. Iversen (udg.): Den nordslesvigske Gruppes og Det sønderjyske

Venstres forhandlingsprotokol 1920. (SJy Ãrb 1970, s. 89-108).

Frantz v. Jessen: Håndbog $\mathrm{i}$ det slesvigske spørgsmåls historie 1900-1937. III: 1920-37. 1938.

A. H. Feilberg Jørgensen: Grænselandet i det sidste århundrede 1830-1940. 1947.

Harald Jørgensen: Genforeningens statspolitiske baggrund. 1970.

Tage Kaarsted: Påskekrisen 1920. 1969.

Tage Kaarsted (udg.): Ove Rodes dagbøger. 1972.

Th. Kaufmann: Minder og tanker. 1962.

Kai Edvard Larsen: Den danske presse i Sønderjylland 1838-1970. (Pressehistorisk Arbog 1970 s. 47-66).

Kai Edvard Larsen: Et halvt århundrede i grænselandet. 1969.

Jette Røddich Nielsen: Det danske Socialdemokratis politik i Sonderjylland 1920-29. Manuskript, Ärhus 1971.

Jakob Petersen: En kort oversigt over folketingsvalgene 1920-1935. (Sprogforeningens Årsberetning 1938-39).

Jakob Petersen (red.): Kulturelle forbold i Sønderjylland 1920-42. 1943. Politikens Danmarks bistorie bd. 13. 1971.

M. Refslund Poulsen: Erindringer I-II. 1955-57.

Erik Rasmussen og Roar Skovmand: Det radikale Venstre 1905-55. 1955. P. J. Refshauge: Bonden der blev landråd. 1941.

Rigsdagstidende 1919-21.

O. D. Schack: Grænsesind. 1970.

Inger Svane: Vxlgerforeningen og de dansksindede nordslesvigeres politik 1906-10. (SJy Ärb 1973, s. 76-198).

Nic. Svendsen: Sønderjydsk skæbne I-III. 1953-68.

Sønderjylland og de politiske partier. (Pjece, udg. af Socialdemokratiet) 1919.

Sonderjyllands historie V. 1932-33.

Ingeborg Refslund Thomsen: Hjemme i Nordslesvig. 1961.

Niels Thomsen: Dagbladskonkurrencen 1870-1970. 1972.

Svend Thorsen: Delt efter anskuelser. 1970.

Svend Thorsen: Mennesker i politik. 1962.

Svend Thorsen og Nic. Svendsen: På vej til Danmark. 1935.

Venstre i 100 ar. II. 1970.

Kursiv angiver forkortelser $i$ henvisningerne. 


\section{NO'TER OG HENVISNINGER}

\section{POLITISK UDVIKLING FØR APRIL 1920}

1. Ved at sammenholde fremtrædende forhandlingstilhæengere med do. Ảbenråfolk ses det, at disse stort set var de samme. (Inger Svane: Vælgerforeningen og de dansksindede nordslesvigeres politik 1906-10; H. P. Hanssens arkiv: Korrespondancesager vedr. H. P. Hanssens virksomhed som dansk rigsdagsmand - indeholder en fortegnelse over Den nordslesvigske Gruppes meningsfæller; Vælgerforeningens arkiv: Forhandlingsprotokol 1908-21 - bl. a. underskrivere af flertals- og mindretalsresolutionen 16. aug. 1919).

2. Fyns Tidende 27/11-18.

3. Ove Rodes Dagbrger s. $213 \mathrm{f}$.

På lignende måde udtalte han sig på et møde, som Det konservative Folkepartis, Venstres og Det radikale Venstres presseorganisationer havde indbudt til i København i dec. 18. (Frantz v. Jessen, s. 199).

4. Hmd. $11 / 8-20$.

5. Refshauge på Den nordslesvigske Gruppes made 23/7-20 (Niels Hansen 23/7-20), C. O. Pedersen i Dybbøl-Posten 14/5-20 og Kloppenborg-Skrumsager i Dannevirke 6/8-20.

6. Marten Refslund Poulsen II s. 28f; Nic. Svendsen II s. 361 og III s. $12 f$. Anders Lebeck skrev i feb. 1920 til H. P. Hanssen: * Jeg angribes for at vare - radikal o og det er det varste, mange af laeserne ved.e (H. P. Hanssens arkiv: Brev fra Lebeck 18/2-20).

7. Troels Fink: Den parlamentariske basis for H. P. Hanssen (Historie XI, 4 1976, s. $434 \mathrm{ff}$ ).

8. Disse Åbenråfolks deltagelse $i$ henvendelsen til H. P. Hanssen gav på Den nordslesvigske Gruppes møde d. 6. april anledning til en skarp kritik. (Niels Hansen 6/4-20).

9. Neergaards arkiv: Opt. s. 119; Niels Hansen 6/4-20.

\section{APRIL 1920}

1. De to grupper holdt atter separate moder.

2. Niels Hansen 6/4-20.

3. Dv. 8/4-20.

4. Dbp. 12/4-20.

5. Niels Hansen 22/4-20.

6. Dbp. 12/4-20.

7. Lebecks arkiv: Referater 6/4-20.

8. Roskilde Dagblad 28/4-20, Dv. 3/5-20.

9. Dv. 27/3-20.

10. Niels Hansen 22/4-20, Lebecks arkiv: Referater 22/4-20.

11. Lebecks arkiv: Referater 22/4-20.

12. Niels Hansen 22/4-20, Lebecks arkiv: Referater 22/4-20.

13. Bogen om H. P. Hanssen s. 29.

M. Refslund Poulsen kalder gruppen Det sønderjyske Venstre; men dette stemmer ikke overens med de to mænds holdning på mødet 23/7, hvor de begge udtalte betænkelighed ved navnet Venstre. Derimod gik de stærkt ind for en sønderjysk gruppe. Det er karakteristisk for flertallet af de læste fremstillinger og erindringer, at kun Det sonderjyske Venstre omtales. 


\section{MA J-JUNI 1920}

1. Neergaards arkiv: Brev fra J. C. Christensen 16/4-20.

2. Politikens Danmarks historie bd. 13, s. 238.

3. Neergaards arkiv: Opt. 4/5-20.

Arbejderforeningen var dannet i 1911 på national baggrund med et socialt program i protest mod, at småkårsstanden blev tilsidesat ved besættelsen af tillidsposterne. Størstedelen af Arbejderforeningen sluttede sig under grænsestriden til Den nordslesvigske Gruppe.

4. Neergaards arkiv: Opt. 4/5-20.

5. H. P. Hanssens arkiv: Brev fra Lebeck 27/4-20.

6. Neergaards arkiv: Opt. 4/5-20.

7. Lebecks arkiv: Referater 6/4-20.

If H. P. Hanssen skulle have forhørt sig om regeringens grænsepolitik, og efter at være blevet orienteret herom skulle han have sagt: \$S er der ikke mere at forhandle om.« (Ingeborg Refslund Thomsen s. 98f).

8. Ikke langere tilbage end 29. april havde Kloppenborg-Skrumsager skrevet til J. C. Christensen, at Flensborggruppen ikke kunne acceptere, at grænsespargsmålet løstes af $\mathrm{H}$. P. Hanssen som minister. Han hjalp sig ind $i$ ministeriet udenom alle andre ved hjælp af de radikale, og han har da også klinet sig godt nok til dem.* (Neergaards arkiv: Brev fra Kloppenborg-Skrumsager til J. C. Christensen 29/4-20).

9. Neergaards arkiv: Opt. 4/5-20.

10. Neergaards arkiv: Opt. 6/5-20.

11. Venstres arkiv: Forhandlingsprotokol 7/5-20.

12. Bladet Dannevirke 1838-1938 s. 293-367; Nis Petersens erindringer; Lebecks arkiv: Modersmålet; H. P. Hanssens arkiv: Breve fra Lebeck.

13. Dv. $4 / 5-20$.

14. Refshauge s. 127.

15. Hmd. 14/5-20.

16. Refshauge s. $127 \mathrm{f}$. Som helhed er dette afsnit om forhandlingerne omkring dannelsen af en senderjysk gruppe ret upræcist.

17. Dv. $14 / 5,15 / 5,19 / 5$, Hmd. 18/5, 21/5, 28/5-20.

18. Dv. $19 / 5-20$.

19. Dv. $19 / 6-20$.

20. Om Flensborggruppens aktiviteter $i$ sommeren 1920 er der ikke fremkommet noget internt materiale. Foruden avismateriale giver en brevveksling mellem red. Andr. Grau, Dybbøl-Posten og statsminister Neergaard indtryk af gruppens forhold til Den nordslesvigske Gruppe og Venstre.

21. Hmd. 15/5-20.

22. Flensborg Avis 18/5-20.

23. Dv. $18 / 5,31 / 5-20$. Dbp. $15 / 5-20$.

24. Dv. 31/5-20.

25. Dv. $18 / 5-20$.

26. Dv. 31/5-20.

27. Dv. 31/5-20.

28. Dv. $18 / 5-20$.

29. Dv. $18 / 5-20$.

30. Hmd. 1/6-20. Dbp. 3/6-20. Neergaards arkiv: Brev fra A. Grau 30/5-20.

31. Dv. 22/6, 24/6-20, Neergaards arkiv: Brev fra A. Grau 30/5-20. 
32. Neergaards arkiv: Breve fra A. Grau 30/5, 18/7-20.

33. Venstres arkiv: Forhandlingsprotokol 3/6-20.

34. København 21/7-20.

35. Hmd. 15/6, 21/6, 22/6-20.

36. Jette Røddich Nielsen: Det danske Socialdemokratis politik i Sønderjylland 1920-29 s. 13ff. Dv. 26/5-20; Stauning kunne ikke få indrejsetilladelse. Hmd. $16 / 7,17 / 7-20$.

37. Nis Nissens arkiv: Brev fra Hans Fink 27/6-20.

38. Hmd. 16/7-20, Dannevirke omtaler et lignende udvalg 24/6-20.

39. Hmd. 21/5, 28/5, 26/6, 17/7-20.

40. Hans Fink skrev om sit partitilhørsforhold: * Jeg troede i grunden at vare en god venstremand, men jeg synes, man bliver lidt vammel ved det, særlig i det sønderjyske spørgsmål, og andet kan man jo snart ikke regne med, da det optager os så fuldt og helt, så alle partisporgsmålene i Danmark bliver underordnet.* (Nis Nissens arkiv: Brev fra Hans Fink 27/6-20).

\section{JULI 1920}

1. H. P. Hanssens arkiv: Brev fra Lebeck 5/7-20.

2. Lebecks arkiv: Opt. 10/7-20, Neergaards arkiv: Opt. s. 157. Optegnelserne om begivenhederne $\mathrm{i}$ juli måned 1920 er efter Neergaards egen angivelse nedskrevet d. 23. og 25. juli.

3. Neergaards arkiv: Opt. s. 157.

4. Neergaards arkiv: Brev fra A. Grau 18/7-20.

5. Lebecks arkiv: Opt. 10/7-20.

6. Lebecks arkiv: Opt. 10/7-20.

7. Neergaards arkiv: Opt. s. 158.

8. Hmd. 11/8-20.

9. Neergaards arkiv: Opt. s. $158 \mathrm{f}$.

10. Hmd. 11/8-20.

11. Thulstrups arkiv: Program.

12. Hmd. 13/7-20.

13. Neergaards arkiv: Brev fra A. Grau 18/7-20.

14. H. P. Hanssens arkiv: Brev fra Thulstrup 20/7-20.

15. Appels arkiv: Brev og telegram fra Thulstrup 24/7-20.

16. Kobenhavn 21/7-20.

17. Hmd. 19/7-20.

18. Refshauge s. $128 \mathrm{f}$.

19. Appels arkiv: Brev fra Thulstrup 21/8-20.

20. Niels Hansen 23/7-20.

21. Lebecks arkiv: Referater 23/7-20, Niels Hansen 23/7-20.

22. Niels Hansen $23 / 7-20$.

23. Niels Hansen 23/7-20, Lebecks arkiv: Referater 23/7-20.

24. Appels arkiv: Brev fra Thulstrup 24/7-20.

25. Lebecks referat viser, at Nissen tænkte på udtalelsen i København 21/7-20.

26. Lebecks arkiv: Referater 23/7-20, Niels Hansen 23/7-20.

27. Hmd. 4/8-20.

28. Hmd. 24/7-20.

29. Appels arkiv: Brev fra Thulstrup 24/7-20.

30. Niels Hansen 23/7-20, Hmd. 11/8-20. Dette udvalg omtales ikke i avisreferatet fra mødet. (Hmd. 24/7-20). 
31. Lebecks arkiv: Referater 23/7-20, Refshauge s. 129.

32. Appels arkiv: Brev fra Thulstrup 21/8-20.

33. Appels arkiv: Telegram fra Thulstrup 24/7-20 - indleveret om aftenen d. 23.

34. Appels arkiv: Breve fra Thulstrup 24/7, 21/8-20.

35. Hmd. 24/7-20.

36. Appels arkiv: Brev fra Thulstrup 24/7-20.

37. H. P. Hanssens arkiv: Brev fra Th. Thomsen 24/7-20.

38. Lebecks arkiv: Opt. (udkast til brev til Aage Friis 15/5-20). Lebecks arkiv: Modersmålet (brev fra Aage Friis 18/5-20).

39. Hmd. 11/8-20.

40. Appels arkiv: Telegram fra Thulstrup 24/7-20.

41. Neergaards arkiv: Brev fra A. Grau 18/7-20 (fortæller om det forestående mode), Hmd. 24/7-20, Dv. 27/7-20.

42. Neergaards arkiv: Brev fra J. C. Christensen 27/7-20.

Navnene på deputationens medlemmer findes i Lebecks arkiv: Referater 10/7-20.

43. Dbp. $24 / 7-20$.

44. Dv. $24 / 7-20$.

45. Dv. $29 / 7-20$.

46. Dv. 26/7-20.

47. Neergaards arkiv: Brev fra J. C. Christensen 27/7-20.

48. Neergaards arkiv: Telegram fra A. Grau 28/7-20.

\section{FORHANDLINGER I AUGUST 1920}

1. Det sønderjyske Venstres forhandling med Venstre var åbenbart blevet udskudt nogle dage. Derimod havde Flensborggruppens Venstre forhandlet.

2. Venstres arkiv: Forhandlingsprotokol 3/8-20.

Iøvrigt kunne henvises til valgloven $\S 28$ : Ingen må melde sig til samtidigt valg $\mathrm{i}$ forskellige amtskredse (storkredse) eller som kandidat for mere end ét parti eller anmelde sig udenfor partierne og samtidig slutte sig til eller støtte et parti. (Rigsdagstidende: tillæg C 1919-20).

3. Venstres arkiv: Forhandlingsprotokol 3/8-20.

4. Dv. 4/8-20, Dbp. 4/8, 5/8-20.

5. Appels arkiv: Brev fra Thulstrup 21/8-20.

6. H. P. Hanssens arkiv: Brev fra Lebeck 5/8-20.

7. Hmd. 7/8-20; desuden kan nævnes at J. H. Schmidt på Den nordslesvigske Gruppes møde d. 10/8 udtalte harme over, at en kongerigsk venstreredaktør forbød en slesvigsk venstreredaktør at skrive. (Lebecks arkiv: Referater $10 / 8-20)$.

8. Hmd. 5/8-20.

9. Hmd. 6/8-20.

10. Lebecks arkiv: Referater $10 / 8-20$.

11. Hmd. 11/8-20.

12. Lebecks arkiv: Referater $10 / 8-20$.

13. Lebecks arkiv: Opt. 3/10-20.

14. Lebecks arkiv: Referater 10/8-20.

15. Hmd. 11/8-20.

16. Refshauge s. 130.

17. Hmd. 11/8-20, Lebecks arkiv: Referater 10/8-20.

18. Neergaards arkiv: Brev fra H. P. Hanssen 11/8-20, Hmd. 11/8-20. 
19. Appels arkiv: Brev fra Thulstrup 21/8-20.

20. Refshauge s. 129f, Appels arkiv: Brev fra Thulstrup 21/8-20.

21. Appels arkiv: Brev fra Thulstrup 21/8-20.

22. Lebecks arkiv: Opt. 3/10-20.

23. Thorsen s. 49, Ingeborg Refslund Thomsen s. $91 \mathrm{f}$ (næunt $\mathrm{i}$ forbindelse med H. P. Hanssens udnævnelse til minister $i$ juni 1919).

24. Hmd. 12/8-20.

25. Hmd. 14/8-20 (udtalelse $11 / 8$ ).

\section{SAMMENFATNING}

1. Græensevagten 1919-20, II s. 485.

2. Et Tilbageblik III s. 298.

H. P. Hanssens arkiv: Optegnelser til foredrag 1923-26 (opstillingsmøde 8/3-24).

3. Grænsevagten 1919-20, II s. 485-89.

4. Lebecks arkiv: Opt. (udkast til brev til Mads Gram 4/9-21).

5. Grænsevagten 1919-20, II s. 485-89. 